\title{
The Impact of Cellular Proliferation on the HIV-1 Reservoir
}

\author{
Maria C. Virgilio ${ }^{1,2}$ (D) and Kathleen L. Collins ${ }^{1,2,3, *}$ \\ 1 Cellular and Molecular Biology Program, University of Michigan, Ann Arbor, MI 48109, USA; \\ mcvirgil@umich.edu \\ 2 Department of Internal Medicine, University of Michigan, Ann Arbor, MI 48109, USA \\ 3 Department of Microbiology and Immunology, University of Michigan, Ann Arbor, MI 48109, USA \\ * Correspondence: klcollin@umich.edu
}

Received: 17 December 2019; Accepted: 18 January 2020; Published: 21 January 2020

check for updates

\begin{abstract}
Human immunodeficiency virus (HIV) is a chronic infection that destroys the immune system in infected individuals. Although antiretroviral therapy is effective at preventing infection of new cells, it is not curative. The inability to clear infection is due to the presence of a rare, but long-lasting latent cellular reservoir. These cells harboring silent integrated proviral genomes have the potential to become activated at any moment, making therapy necessary for life. Latently-infected cells can also proliferate and expand the viral reservoir through several methods including homeostatic proliferation and differentiation. The chromosomal location of HIV proviruses within cells influences the survival and proliferative potential of host cells. Proliferating, latently-infected cells can harbor proviruses that are both replication-competent and defective. Replication-competent proviral genomes contribute to viral rebound in an infected individual. The majority of available techniques can only assess the integration site or the proviral genome, but not both, preventing reliable evaluation of HIV reservoirs.
\end{abstract}

Keywords: HIV-1; latency; HSPC; T cell; proliferation; differentiation; integration; provirus

\section{Introduction}

Human immunodeficiency virus (HIV) is a chronic viral infection that causes acquired immunodeficiency syndrome (AIDS) if left untreated. HIV primarily targets the host immune system by infecting CD4+ T cells, which often leads to the death of the infected cell. With the development of antiretroviral therapy (ART) to block new infections, it was hoped that with time, all of the HIV infected T cells would be eradicated either through immune mediated clearance or cytotoxic effects from the replicating virus. However, a discordance between the amount of HIV mRNA and proviral (genomic, integrated DNA) sequences was discovered in that there was much more HIV DNA than mRNA. This indicated HIV could survive in an integrated but latent form. The main cellular reservoir was discovered to be resting memory CD4+ T cells [1,2], although other reservoirs have since been discovered. Soon after, researchers calculated the mean half-life of latently-infected resting memory T cells to be nearly 44 months and that clearance of the latent reservoir could take 70 years or more $[3,4]$.

HIV relies upon virally encoded reverse transcriptase (RT), an enzyme that is capable of reverse transcribing the viral genomic mRNA into a double-stranded DNA genome that is transported into the cell nucleus and permanently integrated into the host chromosome. As RT is particularly error-prone, causing approximately one error per $10^{4}$ nucleotides (reviewed [5]) it is unlikely that any two 10,000 nucleotide viral genomes will be exactly identical after reverse transcription. Sequencing of latent proviral sequences revealed many cells with the same genetic sequence in multiple cells prompting 
an investigation into how this could be. Because it is also extremely unlikely that any two HIV integration sites are exactly the same, integration site analysis and sequencing of HIV DNA genomes have been used to identify cases in which cellular proliferation is responsible for the production of exact copies of HIV in multiple cells. Each of these methods has their strengths and limitations. The large majority of proviral sequences in an individual are defective [6], meaning they are incapable of producing virus that can infect new cells. Both defective and replication-competent HIV sequences have been found in clonally expanded cells [7-12]. In addition to CD4+ T cells, HIV targets multiple CD4+ cell types in the hematopoietic compartment including macrophages and hematopoietic stem cells, each with a different proliferative potential and ability to contribute to maintenance of the latent reservoir [11-16].

\section{Cell Type, Proliferation Potential, and Growth Stimulus}

\subsection{Introduction to HIV Infection in Patients}

The potential for HIV latency was discovered several decades ago in patients receiving ART. First predictions of time to cure with continued therapy were approximately 2-3 years [17] based on initial results showing a rapid decrease in plasma virus after initiation of ART [18] and a short half-life of actively infected CD4+ T cells [17]. These initial estimates proved wrong due to the presence of cells with a much longer half-life. Further in vitro studies showing that non-virus producing T cells could be stimulated in culture to produce virus provided definitive evidence for the existence of a longer-lived latent reservoir. The major reservoir was thought to be long-lived memory T cells $[2,3,17,19,20]$. There is now evidence that other long-lived cells including naïve T cells, stem cell memory $\mathrm{T}$ cells $[15,21]$ and hematopoietic stem and progenitor cells (HSPCs), contribute to the reservoir [16,22]. Virus may rebound upon interruption of ART through cellular stimulation and differentiation from cells within the latent reservoir. However, T cells and HSPCs have very different proliferative potentials and differentiation capabilities that contribute to viral latency and maintenance of the viral reservoir. The extent to which other long-lived cells such as tissue resident macrophages contribute to the reservoir is unknown. More work is needed to fully characterize the impact of noncanonical cellular subsets to maintaining the reservoir.

In the bloodstream, HIV targets cells of interest through recognition of its primary cellular receptor, CD4, in addition to one of two co-receptors: CXCR4 and CCR5 by the HIV encoded envelope (Env) protein. It has been suggested that all transmitted founder viruses-the initial viruses that establish infection-are CCR5-tropic (reviewed [23,24]), but eventually CXCR4-tropic (X4) viruses predominate in the most infected individuals [25-28]. Exceptions to CCR5-tropic (R5) founder viruses are well established and often found in CCR5-/- individuals [29,30]. Homozygous loss of CCR5 is usually due to a naturally occurring 32 base pair deletion in CCR5 (CCR5 $\Delta 32$ ), and homozygous individuals are highly resistant to HIV infection [30-32]. Both X4-tropic and dual-tropic viruses (with Env that can recognize both CCR5 and CXCR4) have been found in CCR5 $\Delta 32$ homozygous individuals $[33,34]$. Although CXCR4 is more widely expressed in the hematopoietic compartment, both CCR5 and CXCR4 are expressed on CD4+ T cells and HSPCs $[12,16,35,36]$. CCR5 is highly expressed on macrophages and activated $T$ cells, but very little is found on quiescent $T$ cells [37-40]. For HSPCs, the more primitive stem cells express less CCR5 than progenitors, however proviral sequences that express X4 and R5-tropic Env have been identified in both stem cell and progenitor populations [12,16,35].

\subsection{Hematopoietic Potential}

HSPCs possess enormous proliferative potential, are extremely long lived, and differentiate into all the hematopoietic lineages through hematopoiesis. Hematopoiesis is the process of building and maintaining the entire hematopoietic compartment through many stages of differentiation starting from the most primitive hematopoietic stem cells (HSCs). Differentiation initially proceeds from the long-and short-term HSCs, which divide and differentiate into progenitors that eventually terminally differentiate 
into all the cells that make up the hematopoietic system, including dendritic cells, macrophages, erythrocytes, megakaryocytes, $\mathrm{B}$ and $\mathrm{T}$ cells. With each step through the differentiation process, stemness is lost along with proliferative potential (reviewed [41,42]). Although most differentiated cells in the hematopoietic compartment are tissue-resident, HSPCs remain primarily quiescent in the bone marrow, except during times of stress or need (reviewed [43]).

HSPCs express CD4 at low levels, are capable of being infected with both X4 and R5-tropic HIV in vitro, and proviral sequences have been identified in HSPCs from patients $[11,12,16,22]$. Identical proviral sequences, including the same insertion site in the patient genome, were found in multiple compartments of the hematopoietic lineage including HSPCs, PBMCs (peripheral blood mononuclear cells), and BMMCs (bone marrow mononuclear cells). A subset of these clonal sequences was matched to expressed cell-free virus [11]. Some cells with clonal proviral sequences matching provirus from HSPCs were not CD4+. The virus detected was defective such that natural infection could not have occurred. These infected lineages could only have arisen through differentiation into multiple lineages from a single, more primitive cell [12]. This demonstrates the potential of a single infected HSPC to be infected, proliferate, and differentiate into several lineages while also carrying provirus (Figure 1a).

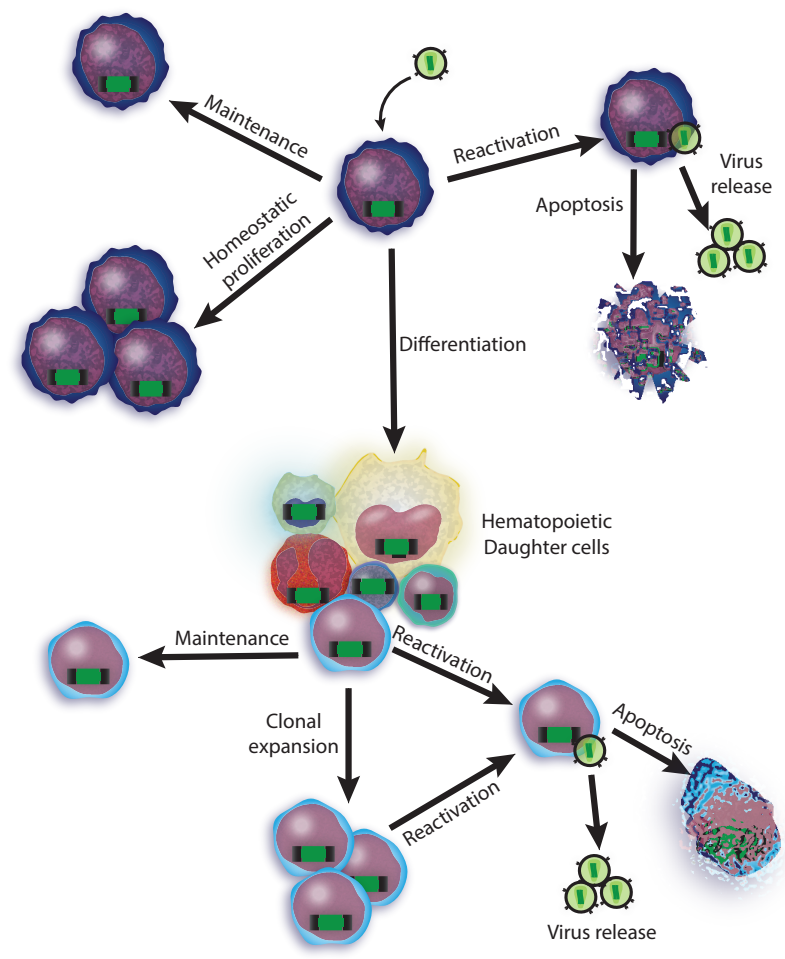

(a)

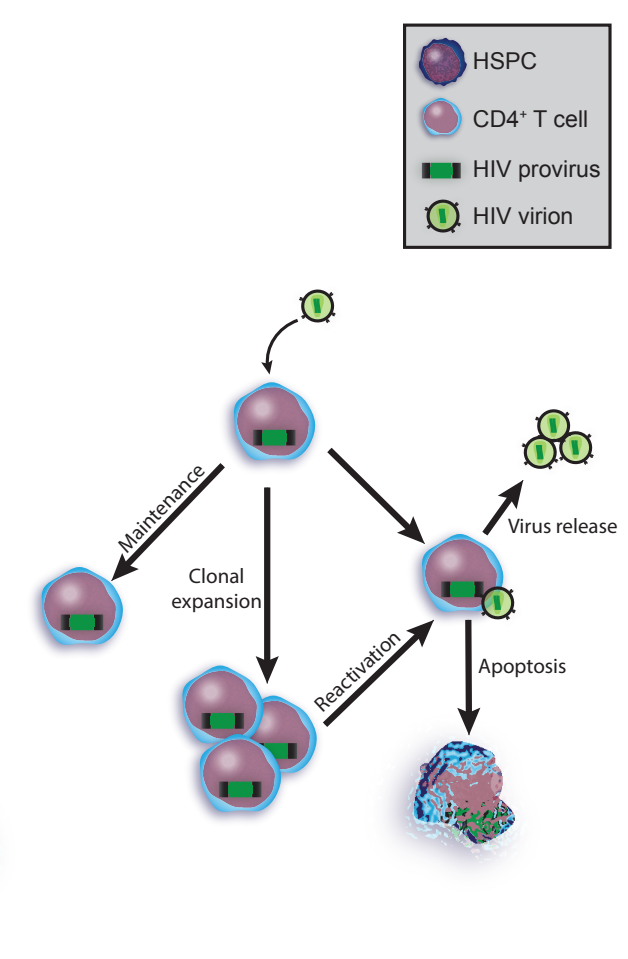

(b)

Figure 1. Cellular potential and clonal expansion. (a) A hematopoietic stem cell becomes infected with human immunodeficiency virus (HIV) and can follow many fates including maintenance of the population, differentiation, and reactivation (top). Some of the daughter cells can clonally expand (bottom); (b) CD4+ T cell fates. A CD4+ T cell becomes infected and can maintain itself, clonally expand, and reactivate to produce more viruses.

HSPCs are rare and HIV infected HSPCs are even rarer (approximately 2.5 proviruses per million HSPCs) with less than 1 in a million HSPCs expected to carry a replication-competent provirus [12]. Latency is preserved in the most quiescent HSPCs and differentiation is associated with higher rates of active infection [44]. A single HSPC harboring an intact virus has great potential to spread provirus through daughter cells and expressed virus to form new infections (Figure 1a). The high proliferative potential, long lifespan, and capability of populating the body with infected daughter cells of all 
lineages, not just T cells, makes HSPCs a unique reservoir with exceptional potential for maintaining the viral reservoir.

\section{3. $T$ Cell Reservoirs}

Once $T$ cells have committed to the $C D 4$ lineage, the naïve $T$ cells $\left(T_{N}\right)$ have the greatest proliferative capacity of the $\mathrm{CD} 4+\mathrm{T}$ cells and lose their proliferative potential as they differentiate into the polarized, functional subsets: $\mathrm{T}_{\mathrm{H} 1}, \mathrm{~T}_{\mathrm{H} 2}, \mathrm{~T}_{\mathrm{H} 9}, \mathrm{~T}_{\mathrm{H} 17}, \mathrm{~T}_{\mathrm{FH}}, \mathrm{T}_{\text {reg }}$ (reviewed [45]). After the peak of infection and clearance of foreign antigen, greater than $90 \%$ of the $\mathrm{T}_{\mathrm{H}}$ population dies. The remaining cells convert into long-lived memory cells that are primarily quiescent and do not rely on peptide-bound major histocompatibility complex II stimulation for maintenance (reviewed [46]). T cells appear to be most susceptible to HIV infection after activation but before initiation of quiescence [1], while the latent reservoir in T cells is most likely established during the effector to memory transition [47]. These memory cells then rely upon homeostatic proliferation for maintenance until they are re-activated (Figure 1b).

Within the memory compartment, there are a number of populations of CD4+ T cells with differing proliferative and effector capabilities that have been shown to play a role in maintaining the viral reservoir. The long-lived memory compartment generally follows a sequential differentiation program from $\mathrm{T}_{\mathrm{N}}<\mathrm{T}_{\mathrm{SCM}}<\mathrm{T}_{\mathrm{CM}}<\mathrm{T}_{\mathrm{TM}}<\mathrm{T}_{\mathrm{EM}}<\mathrm{T}_{\mathrm{TE}}$ where proliferative potential and life-span are lost as differentiation state is gained (Figure 2) [48,49]. Among $\mathrm{T}$ cell subsets, $\mathrm{T}_{\mathrm{N}}$ have the greatest proliferative potential but the slowest rate of growth with an estimated proliferation rate of only $0.2 \%$ per day [50,51]. Of the two major memory subsets, effector memory $\mathrm{T}$ cells, $\mathrm{T}_{\mathrm{EM}}$, have rapid proliferation rates of $4.7 \%$ per day compared to $1.5 \%$ for $\mathrm{T}_{\mathrm{CM}}$ [50]. $\mathrm{T}_{\mathrm{EM}} \mathrm{s}$ are short lived cell populations needing continuous cell replenishment in vivo [50] and low proliferative potential compared to $\mathrm{T}_{\mathrm{CM}}[52,53]$. To grow and maintain their existence, CD4+ T cells rely on IL-7 and IL-15 for homeostatic proliferation [52,54,55]. Experiments stimulating proliferation of latently-infected T cells using IL-7 surprisingly did not result in viral reactivation alone [56,57] or together with IL-2 [58] (IL-2 reviewed here [59]), indicating that homeostatic proliferation can maintain the reservoir over time. However, a combination of IL-15 and the pan-histone deacetylase inhibitor, vorinostat, [60] or antigenic stimulation using anti-CD3/anti-CD28 can efficiently reactivate latent HIV in cultured central memory $\mathrm{T}$ cells and lead to virus-induced cell death $[57,58]$. Therefore, cellular stimulation signals and epigenetic drugs are capable of reactivating the virus in vitro and may be able to lessen the viral reservoir in patients, however, clinical trials using vorinostat have thus far not succeeded in decreasing the size of the latent viral reservoir [61].

Central memory $\mathrm{T}$ cells, $\mathrm{T}_{\mathrm{CM}}$, are classically considered the primary reservoir of latent HIV infection. However, clonally expanded latent infections have been found in many memory $\mathrm{T}$ cell subsets $[7,9,15,21,62]$. CD4+ $\mathrm{T}$ memory stem cells, $\mathrm{T}_{\mathrm{SCM}}$, are the most recent addition to the $\mathrm{T}$ cell memory compartment and are derived from naïve $T$ cells. They are capable of maintaining a stem-like phenotype in addition to having central memory attributes $[63,64]$. Recent work has demonstrated $\mathrm{T}_{\mathrm{SCM}}$ are more susceptible to in vitro infection using a GFP-encoding vesicular stomatis virus $\mathrm{G}$ protein (VSV-G) pseudotyped HIV and similarly susceptible with a GFP-encoding R5-tropic HIV isolate compared to $\mathrm{T}_{\mathrm{CM}}$ even though $\mathrm{T}_{\mathrm{SCM}}$ have slightly less CCR5 cell surface expression [21]. While $\mathrm{T}_{\mathrm{SCM}}$ represent a much smaller fraction of the memory compartment they are proportionately more likely to contain HIV DNA than $\mathrm{T}_{\mathrm{CM}}$ or $\mathrm{T}_{\mathrm{EM}}$ [21]. Identical provirus sequences found in $\mathrm{T}_{\mathrm{SCM}}$ were also in more differentiated $\mathrm{T}$ cell subsets including $\mathrm{T}_{\mathrm{CM}}$ and $\mathrm{T}_{\mathrm{EM}}$, demonstrating $\mathrm{T}_{\mathrm{SCM}}$ contribute to the latent reservoir through both proliferation and differentiation, though the integration sites were not determined to confirm clonality [21]. When considering the ability of proviruses found in memory $\mathrm{T}$ cell subsets to produce virus either by viral outgrowth assays or by sequencing of near full length (NFL) viral genomes $\mathrm{T}_{\mathrm{SCM}}$ [21], $\mathrm{T}_{\mathrm{EM}}$, and $\mathrm{T}_{\mathrm{N}}$ [15] had more replication-competent provirus sequences than $\mathrm{T}_{\mathrm{CM}}$, making their effective contribution to the functional HIV reservoir much larger $[15,21]$. Their findings are surprising considering central memory $\mathrm{T}$ cells harbor more total HIV DNA. $\mathrm{T}_{\mathrm{SCM}}$ and $\mathrm{T}_{\mathrm{N}}$ both have greater proliferative potential than $\mathrm{T}_{\mathrm{CM}}$, but naïve $\mathrm{T}$ cells have largely been dismissed as contributing to the latent reservoir because they are difficult to infect in vitro, are primarily quiescent, 
and express low levels of CCR5 before activation [37,38]. It is possible that a higher proportion of functional genomes are found in quiescent $\mathrm{T}$ cell subsets because viral latency is tighter and protects the cells from cytopathic effects of activated functional proviral genomes. Interestingly, HSPCs, which are also quiescent in vivo, similarly harbor a higher proportion of functional proviral genomes compared to more differentiated cells [11].

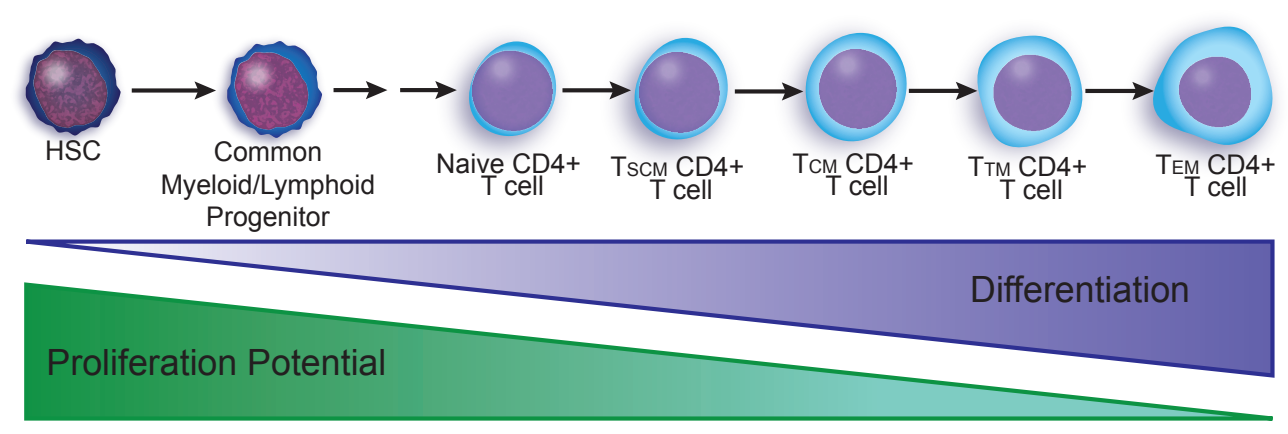

Figure 2. Differentiation and proliferative potential of the latent reservoir. Hematopoietic stem cells (HSC) are multipotent and differentiate into both common myeloid and lymphoid progenitors. Through several more steps of differentiation, naïve CD4+ T cells emerge from the lymphoid lineage as the least differentiated of the terminally differentiated $\mathrm{T}$ cell subsets. $\mathrm{T}$ cells undergo successive rounds of activation and differentiation through memory stem cells $\left(\mathrm{T}_{\mathrm{SCM}}\right)$, central memory $\left(\mathrm{T}_{\mathrm{CM}}\right)$, transitional memory $\left(\mathrm{T}_{\mathrm{TM}}\right)$, to effector memory $\left(\mathrm{T}_{\mathrm{EM}}\right)$.

\section{HIV Sequence Integrity}

Many HIV sequences are clonal, and the large majority of proviruses are defective [6,65]. Although some work has shown only cells carrying defective proviruses can clonally expand [7], cells with replication-competent provirus can be clonal with potential to maintain spreading infection and rebound with interruption of therapy $[8,11,14,66,67]$.

A replication-competent provirus can be thought of as coding for all the necessary structural proteins - gag, pol, and env, and genomic features necessary for transcription including cis regulatory sequences in the 5'UTR such as the major splice donor site (MSD) used in all the spliced viral RNAs, promoter, and transcriptional start site (reviewed [68]). Ultimately, replication-competence is measured by the ability of a provirus to code for new virions that are capable of infecting new cells. Replication-incompetent, or defective proviral genomes can take many forms. They generally have acquired large deletions impacting necessary genomic features including the major structural proteins and regulatory regions. They can also be classified as hypermutated where proviral genomes contain a multitude of point mutations, likely as a result of APOBEC3G activity (reviewed by [69]).

\subsection{Clonality and HIV Sequence Integrity in T Cell Subsets and HSPCs}

As summarized above, CD4+ $\mathrm{T}$ cells have many levels of differentiation. The contribution of each differentiated subset to the functional latent reservoir has only recently begun to be more comprehensively resolved. Lee et al. performed massive single-genome, near-full-length next-generation sequencing on HIV DNA from bulk memory and functionally polarized memory CD4+ T cells: $\mathrm{T}_{\mathrm{H} 1}, \mathrm{~T}_{\mathrm{H} 2}, \mathrm{~T}_{\mathrm{H} 9}, \mathrm{~T}_{\mathrm{H} 17}$, and $\mathrm{T}_{\text {Hneg }}\left(\mathrm{T}_{\mathrm{H}}\right.$ cells that did not fit into the other $\mathrm{T}_{\mathrm{H}}$ subsets) [14]. Of the clonally expanded cells with intact provirus in the polarized $\mathrm{T}$ cell subsets, the majority $(11 \%)$ of the intact sequences were found in the $\mathrm{T}_{\mathrm{H} 1}$ subset. Only defective clonal sequences were found in $\mathrm{T}_{\mathrm{H} 9}$ cells. Additionally, $4 \%$ of sequences in memory CD4+ T cells were genome intact. The intact clonal sequences were phylogenetically mixed, suggesting the sequences did not originate from a dominant plasma strain (active infection), but from proliferation of single cells that become clonal. Viral outgrowth assays confirmed the clonal sequences classified as fully intact were replication-competent [14]. Similarly, Hiener et al. found approximately $5 \%$ of recovered sequences from six individuals were 
replication-competent within $\mathrm{CD} 4+\mathrm{T}$ cell memory subsets [15]. More intact viral genomes were found in $\mathrm{T}_{\mathrm{EM}}, \mathrm{T}_{\mathrm{TM}}$, and $\mathrm{T}_{\mathrm{N}}$ than $\mathrm{T}_{\mathrm{CM}}$, even though HIV DNA was more prevalent in $\mathrm{T}_{\mathrm{CM}}$. Interestingly, the authors identified a clone in one of their participants where $32 \%$ of all the sequences from $T_{\mathrm{EM}} / \mathrm{T}_{\mathrm{TM}}$ cells were identical. The coding region was fully intact except for a deletion in the packaging loop and MSD site [15].

Compared to T cells, HSPC-associated HIV genomes appear more likely to be functional. Based on near-full-length genome amplification and sequencing, approximately $28 \%$ of proviral genomes from HSPCs were estimated to be replication-competent [11] compared to $2 \%-12 \%$ for CD4+ T cells $[6,14,15,65]$. Remarkably, HSPC-derived near-full-length genomes often matched free virus in the bloodstream $(60 \%)$, otherwise known as peripheral virus (PV). This "in vivo outgrowth assay" provides strong evidence that HSPCs can harbor infectious HIV. The functionality of one of the near-full-length HSPC-associated proviruses was further confirmed by demonstrating virus produced from the reconstructed genome could spread in the CCR5 expressing T cell line, MOLT4/CCR5 [11]. Based on these studies, HSPCs, which have the greatest proliferation potential of all the latent HIV reservoirs (Figure 1a; Figure 2), harbor intact proviruses, and contribute significantly to residual PV.

Clonally amplified HIV proviral genomes with signature deletions have appeared in many reports. In particular, a number of groups have reported clonal amplification of proviral genomes containing large deletions removing the MSD site or other regulatory sequences in the $5^{\prime}$ region $[11,15]$. Pinzone et al. aligned whole genome sequences collected from four individuals to look for common genomic changes in donors over time [70]. They classified defective proviruses based on preservation of the two strong splice donor sites in HIV. The first strong splice donor (SD1) is just upstream of gag and is part of the canonical splice pathway, used for all proteins except Gag/Pol. The second, splice donor 4 (SD4), is further downstream and falls just before vpu [71-74]. Sequences with both splice donor sites intact decreased the most over time, followed by those with SD1, and finally SD4. Sequences with neither did not change at all. Unsurprisingly then, sequences preferentially expressing Gag/Pol (those lacking SD1) became more abundant over time, suggesting these deleted proviruses experience less negative selection pressure [11,70]. Their last finding was the most surprising of all. They demonstrated HIV could splice to downstream host genes including STAT5B [75], and in vitro experiments showed a preference for HIV-host chimeric transcripts spliced from SD4 [70].

\subsection{Using HIV Sequences to Determine Clonality and Decay}

Our understanding of the latent reservoir has changed significantly since it was first reported, as has our understanding of clonal expansion and proliferation of provirus-containing cells. Proliferation is not explained by acquisition of drug resistance mutations in pol for participants on ART [10]. In HIV infected individuals on ART, the majority of proviral sequences are clonal due to proliferation, and the frequency of clonally expanded cells increases with time as non-clonal cells decrease (Figure 3) $[7,9,10,76]$. For example, Simonetti et al. showed a replication-competent provirus from a clonal CD4+ T cell represented $13 \%$ of all CD4+ T cells in an infected individual. The site of integration is in a region of the human genome that is mapped to two different places in the reference. In addition, the replication-competency and spreading ability were confirmed by PCR-amplifying the viral sequence as two partially overlapping genomic products and co-transfecting the fragments into cells, then using the produced virus to infect CD4+ T cells from HIV negative donors in vitro [8].

Estimates of total HIV DNA and replication-competent sequences in an HIV-infected person are upwards of 10 million cells distributed amongst hundreds to thousands of clones [9,77]. Reeves et al. broke down the clonal population into estimates for large and small clone contributions [9]. The 100 largest clones in all their participants had approximately $10^{5}$ associated cells. Large clones with replication-competent provirus had an average of $10^{4}$ cells each. The average infected individual also had approximately $10^{7}$ total DNA-containing smaller clones with fewer than 1000 associated cells, and $10^{4}$ small clones with replication-competent provirus [9]. Even though the total amount of HIV DNA does not decrease over time, intact proviruses do. Intact proviruses decayed at a rate of -0.38 to 
$-0.2 /$ year with a half-life of 1.8 to 3.4 years in individuals on ART for $>10$ years [70]. Additionally, some recent work proposes sex-specific differences in the size and composition of the latent viral reservoir $[78,79]$ (sex-specific infection differences reviewed [80]). Despite the gradual loss of intact proviruses over time in treated people, the quantity of cellular clones with intact, replication-competent provirus, and sometimes extreme proliferation rates, challenges previous perceptions of the contribution of proliferating clones containing non-replicating HIV DNA. Instead, future cure strategies must focus on cells with the ability to maintain themselves by proliferation if they will be successful at clearing HIV from the body.

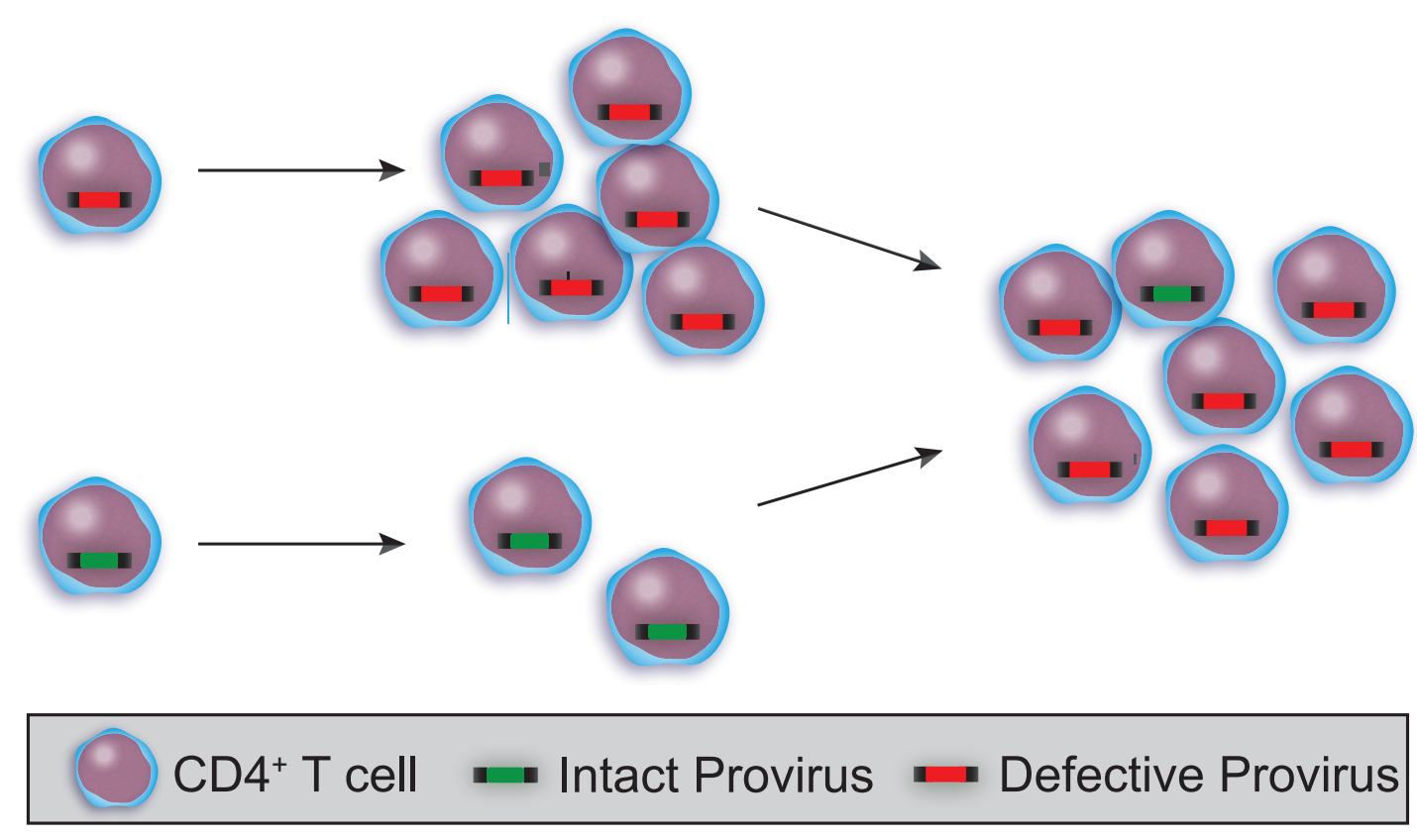

Figure 3. Proliferation of intact and defective proviruses build and maintain the viral reservoir. Cells with intact proviruses (green bar) can sometimes proliferate and expand but do not survive as abundantly as cells harboring defective provirus (red bar) and eventually decrease over time. Proliferation is more abundant for cells with defective proviruses.

\section{Methods of Viral Spread}

\subsection{Cell-to-Cell Viral Spread}

Infection is initiated by either a small number of virions or a single virion (reviewed [81]). Once infection is established, there are two main methods of viral transfer: cell free and cell-to-cell transmission (reviewed [82]). Cell free virions circulate in the bloodstream and can rapidly disseminate. Cell-to-cell transmission involves contact between at least one infected cell and another uninfected cell. It is a much slower process, but the overwhelming majority of new infections are from cell-to-cell spread and not cell-free virus $[83,84]$. As an antigen presenting cell, infected macrophages efficiently transfer HIV to nearby T cells through direct interaction [85-87]. Recently, a host factor involved in cell aggregation, activated leukocyte cell adhesion molecule (ALCAM), was found to mediate cell-to-cell transmission of HIV to T cells [88]. HIV proteins can also contribute to cell-mediated transfer. HIV Env is expressed and trafficked to the cell surface during active infection where it can interact with HIV receptors on uninfected cells, sometimes fusing cells together into syncytia [89]. Cell-to-cell spread minimizes the exposure of virus to the host immune system and lessens selective pressures [90].

\subsection{Viral Evolution and Insufficient ART}

Viral evolution in tissues with sub-optimal ART concentrations has been suggested as a potential source of residual viremia, continued viral evolution, and an important means of maintaining the 
viral reservoir in infected individuals [91]. However, the overwhelming majority of available evidence strongly suggests this is unlikely [13,92-99]. Instead, viral evolution early after initiation of ART may be an artifact of sampling long-lived cells that were generated before the initiation of ART or during acute infection [9,98-101]. After one week of ART, clonal expansion is primarily responsible for driving viral persistence and not viral evolution $[9,13,96]$. Single-genome sequencing (SGS) (Table 2) of samples taken from patients who initiated ART shortly after becoming infected shows there is little change in the provirus sequences after several years on ART, further providing evidence that tissues, or "sanctuary sites," with lower drug concentrations do not contribute to maintenance of the viral reservoir [77].

If suboptimally treated tissues exist and contribute to persistent viremia, then increasing the dosage or adding new treatments to current regimens should limit viral evolution by reaching any untreated or under-treated tissues. However, studies testing the addition or increase in dosage of Raltegravir, an integrase inhibitor, to ART regimens have disagreed on whether modifying ART is helpful. One study claimed Raltegravir did not alter residual viremia in the gut [102] or alter viral evolution [97] while another group found Raltegravir added to normal ART regimes allowed the detection of unintegrated HIV DNA that could only be present in the setting of active viral replication [103]. Nevertheless, there is little evidence that any low level replication that may occur, significantly changes viral production or promotes viral sequence alterations towards drug-resistant variants $[93,102]$. Viral evolution is unlikely with standard ART regimes.

\subsection{Expression from Unintegrated Virus}

In addition to the stably integrated form, HIV proviral DNA can exist in labile form-that is, as an unintegrated complex - and some have speculated that labile forms contribute to persistent viremia. However, these forms of HIV are extremely unstable and only last up to a couple of days [104]. They can, however, last longer in quiescent cells [105], and importantly can become integrated if the infected cell becomes activated before the pre-initiation complex has decayed [38].

\section{Insertion Site}

As a retrovirus, one of the defining features of HIV infection is reverse transcription post-entry into the host cell. Reverse transcription is the process of converting the viral single-stranded RNA genome into a double-stranded DNA genome via the virally encoded reverse transcriptase (RT) (reviewed [106]). The dsDNA is then transported into the nucleus where it utilizes a mix of host- and virus-encoded proteins to permanently insert itself into the human chromosome (reviewed [107]).

\subsection{Integration Site and Genome Capture Techniques}

Integration site determination is complicated by the fact that each provirus has a single integration site and often a single integration per cell $[108,109]$. Sequencing across the integration site from the provirus into the host DNA can be challenging. Techniques must be able to capture an HIV sequence that is likely to be different than other proviral sequences due to deletions or mutations, and the host sequence adjacent to the provirus is unknown. Even the best designed primers may not be able to bind the HIV sequence. This challenge has led to the development of several methods of integration site analysis (see the Techniques Section below). One major caveat to integration site studies is that most of the technologies do not allow the determination of whether the clonal proviral genomes are replication-competent.

\subsection{Integration Site Preferences}

Retroviruses exhibit some differences in their integration site preferences [110,111]. HIV preferentially integrates into introns of actively expressed genes (Figure 4d,e) [38,65,112-115]. Unlike many other retroviruses, HIV is capable of infecting non-dividing cells, and the cDNA genome is able to traverse the nuclear membrane through interaction between viral and host proteins [64,116-120]. 
The nuclear pore complex (NPC) and associated nucleoporin proteins (Nups) aid in facilitating HIV integration into euchromatic regions of the host genome through interactions between the viral capsid and DNA genome-protein integration complex [117]. This results in a strong preference for integration into chromatic regions near the nuclear pores. Integrations near the nuclear envelope is common to lentiviruses with the exception of the gammaretrovirus, M-MLV (Moloney murine leukemia virus) [121].

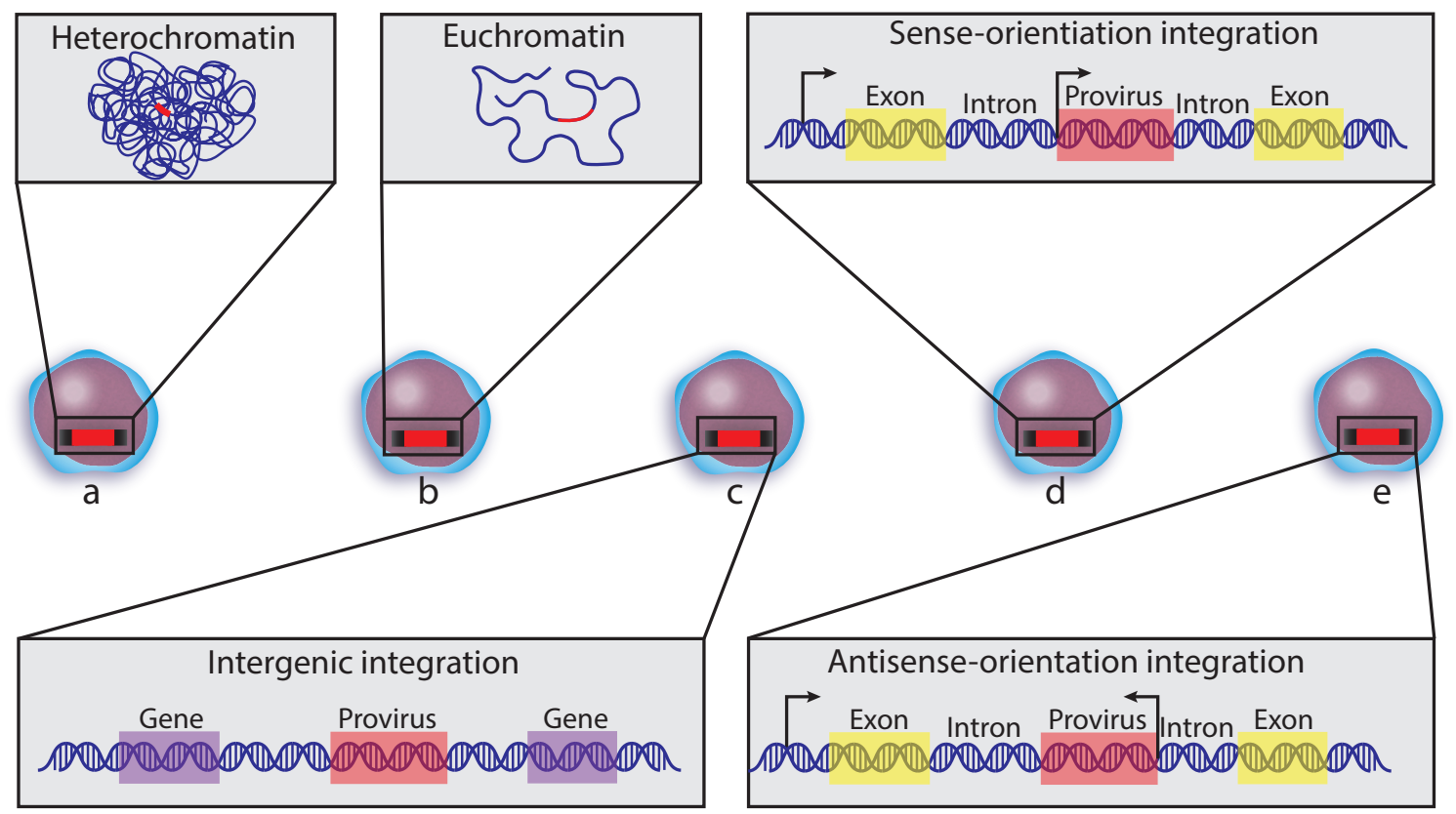

Figure 4. Transcriptional orientation and chromatin states of proviruses. HIV proviruses (red bars) can be found throughout the genome, in both inactive regions of the host genome like heterochromatin (a) or actively expressed regions such as euchromatic regions (b). They can also be detected in intergenic regions (c) but are primarily found as integrations within introns of actively expressed genes (d,e) and can integrate in either the sense- or antisense-orientation regardless of their genomic location $(\mathbf{d}, \mathbf{e})$. Arrows indicate TSS and direction of transcription.

Mapping the integration site of HIV proviral genomes is exceptionally useful for determining the extent of proliferation each clone has undergone, when clones originated, and the balance between clonal to non-clonal proviruses. This is possible based on the assumption that no two integration events are likely to be exactly the same by chance. With this understanding, one group followed three patients on ART over a period of $>10$ years, sampling each participant at three timepoints: $1-2$ years, 4-8 years, and 11-13 years post ART initiation. All of the participants had identical viral sequences integrated in multiple cells that persisted over all the sampling timepoints, indicating the infected cells underwent proliferation [76]. Similarly, Maldarelli et al. mapped the integration site of HIV proviruses from thousands of PBMCs taken from infected individuals on ART. Approximately $40 \%$ of the integrations were in clonally expanded cells. In one of their donors, they astonishingly found as many as half of all integrations sequenced mapped to a single clone [122]. Some groups have also claimed HIV has a strong preference for integration into repetitive DNA, Alu rich, regions of the genome independent of the transcriptional level of the nearby genes, though these findings are controversial $[7,112]$ and others have demonstrated there is no integration preference for many types of repetitive DNA sequences [115].

Many HIV genomes from patients on ART have been found integrated into genes implicated in human cancer, most frequently $B A C H 2, M D C 1$ [76,114,115], MKL2 [7,122], and in genes associated with cell growth and mitosis, including STAT5B, PARP8, DDX6, PKP4, and MAP4 [7,75,76,114,115]. One study found all of the integrations in $B A C H 2$ and $M K L 2$ were in the sense orientation $[115,122]$ and 
mapped to introns upstream of the transcription start site (TSS) [122]. When they compared integration sites from acute HIV infection in vitro in both HeLa and CD34+ hematopoietic stem cells, integrations in $B A C H 2$ and $M K L 2$ were mapped in both the sense and antisense orientation and integrations were dispersed throughout the genes [122]. This suggests that in some cases, there is selective pressure and survival advantage for integrations in a specific orientation and location in genes involved in cell growth and survival even if pre-ART integrations were more stochastic. However, when looking at the overall pattern of integration orientation across all patient data, there seems to be a preference for integration antisense to transcription (Figure 4e) [7,112,115,122,123], suggesting there is much still to be learned about integration site and orientation direction of proviruses and whether proviral integration into genes regulating cell growth affects cell survival. Interestingly, the one integration site from a treated patient sample that has been linked to both an infected CD34+ progenitor cell with naturally high proliferative potential and clonally expanded differentiated progeny was more than $50 \mathrm{~KB}$ from any genes (Figure 4c) [11]. Amplification of this provirus by cellular proliferation was thus unlikely to be due to insertion into genes that regulate growth as the insertion site was intergenic and far from a gene. Any cellular proliferation was therefore likely to be from the innate proliferative capacity of the infected cell(s) and not from dysregulation of nearby genes.

Whether HIV actually gains a proliferative advantage from integration into cancer-associated genes is debated $[7,115]$. Cohn et al. claim the enrichment of clonal integrations in cancer-associated genes is as frequent as integrations in highly expressed genes and thus there is no preferential integration advantage for cancer-related genes. Instead, integrations in cancer-associated genes, transcriptionally active, and genic-regions of the genome decrease in ART-treated compared to untreated individuals [7]. Assuming a preference for integration into cancer and cell growth associated genes, non-AIDS related cancers are surprisingly rare in HIV infected individuals thus far in the epidemic. Cancers associated with HIV infection instead commonly arise from other viral infections such as Epstein-Barr virus [124,125] with rare exceptions [126]. However, pharmacological inhibition of a cancer-related gene decreased HIV-infected cell numbers in vitro [127]. Inhibition of BIRC5 was effective at clearing many HIV infected cells including those latently- and actively-infected. BIRC5 (Baculoviral IAP repeat containing 5) is a member of the inhibitor of apoptosis (IAP) gene family. Whether the cells exclusively affected by the treatment contain proviral insertions in BIRC5 or if treatment can broadly clear HIV infected cells remains to be determined.

\subsection{Informing Cure Strategies from Integration Sites}

Once HIV has integrated into a host chromosome, it persists for the life of the cell. If the HIV genome is replication-competent and if the infected cell is long-lived, there is potential for the provirus to become activated and contribute to viremia at any point. Resting CD4+ T cells have a long half-life [3] and HIV DNA levels remain stable in patients on ART after many years. Resting CD4+ T cells can maintain themselves under a quiescent state or through homeostatic proliferation without reactivation of the latent virus. Hence, any prolonged interruption of therapy creates potential for viral rebound.

Latency reversal strategies have mostly focused on "shock and kill", an approach broadly described as shocking latent HIV in quiescent cells to transcriptionally awaken. Transcriptionally active HIV produces proteins that are usually either toxic to the cell or reveal the infected cell to the immune system for clearance. The epigenetic state at the site of viral integration is of great interest for treatments involving histone deacetylase inhibitors (HDI) as they have been proposed as a potential therapeutic option for latency reversal (Figure $4 a, b$ ). The pan-HDI, vorinostat, has had mixed success in clinical trials for decreasing the latent $\mathrm{T}$ cell reservoir [128]. Recent work testing the effectiveness of vorinostat and other pan-HDI on reversing the latent reservoir in HSPCs has demonstrated limited efficacy. Instead, a combination of class-I selective HDI treatments appear to be more effective [129]. Understanding the contribution of integration site selection initially by HIV and over time in vivo has profound implications for curative strategies. As such, there is a database created to collect known integration site information [130]. 


\section{Techniques}

The phenomenon of clonality can be determined in many ways. The most assured way is to capture the integration site, however, by doing so, information is not captured about the provirus sequence. This is because current laboratory techniques are either optimized to examine the provirus-host chromosome junction (Table 1) or to capture the proviral sequence (Table 2), but not both. Some groups have combined and modified existing techniques to determine the HIV integration site and genome sequence integrity from a single cell (or genomic equivalent) containing an HIV provirus (Table 3) $[11,115,131]$. Techniques used to measure the latent reservoir are discussed in Table 4. An important caveat to all of the work presented in this review is the method of determining clonality differs between studies and between groups. Sequencing a selection of genes or subgenomic regions to show replication-competency may lead to overestimates of the intact, clonal population as there could be mutations or deletions in other parts of the genome not captured. Only if the integration site as well as the entire HIV genome is sequenced can clonality be definitely determined [9]. Tables 1-4 contain brief descriptions of a selection of techniques used in some of the studies reviewed here as well as some generally used in the field to study HIV latency and proliferation.

Table 1. Integration Site Techniques.

\begin{tabular}{|c|c|c|c|}
\hline Technique & Description & Advantages & Limitations \\
\hline Modified TC-Seq $[7,122]$ & $\begin{array}{l}\text { Sonicate genomic DNA into small } \\
\text { fragments. End-repair DNA fragments. } \\
\text { Add dA-linker to 3' ends. Attach } \\
\text { linkers to 3' ends using dT. Perform } \\
\text { Nested PCR on fragments. Attach } \\
\text { Illumina sequencing adaptors. } \\
\text { Paired-end Illumina sequencing across } \\
\text { integration sites. }\end{array}$ & $\begin{array}{l}\text { High-throughput integration } \\
\text { site analysis } \\
\text { - Clonality determined through } \\
\text { matched integration sites }\end{array}$ & $\begin{array}{l}\text { Provirus sequence } \\
\text { cannot } \\
\text { be determined }\end{array}$ \\
\hline $\begin{array}{l}\text { ISLA (Integration site } \\
\text { loop amplification) } \\
\quad \text { (Figure 5) [76] }\end{array}$ & $\begin{array}{l}\text { Linear extension PCR products from the } \\
\text { 3'end of HIV into chromosome are } \\
\text { amplified with a random decamer } \\
\text { complementary to the host genome } \\
\text { with a U5-priming sequence-tail. The } \\
\text { U5 primer is used as a reverse primer to } \\
\text { convert the ssPCR into a dsPCR of } \\
\text { 3'HIV-chromosome product. Linearized } \\
\text { products produce a genetic barbell with } \\
\text { LTR sequence on either side of human } \\
\text { sequence which can be PCR amplified } \\
\text { and prepared for NextGen sequencing. }\end{array}$ & $\begin{array}{l}\text { High-throughput integration } \\
\text { site analysis } \\
\text { Clever usage of random } \\
\text { decamer-U5 primer for } \\
\text { sequence generation across } \\
\text { integration sites }\end{array}$ & $\begin{array}{l}\text { - } \begin{array}{l}\text { Provirus sequence } \\
\text { integrity cannot } \\
\text { be determined }\end{array} \\
\text { More complicated } \\
\text { method compared } \\
\text { to others } \\
\text { Requires multiple } \\
\text { PCR steps }\end{array}$ \\
\hline $\begin{array}{c}\text { Circular Template } \\
{[11,132]}\end{array}$ & $\begin{array}{l}\text { PCR amplification and sequencing } \\
\text { across the insertion site starting from } \\
\text { genomic DNA from HIV infected cells. } \\
\text { A restriction enzyme (PstI) creates small } \\
\text { provirus-host DNA fragments that can } \\
\text { be ligated together into circular units } \\
\text { and amplified using HIV-specific } \\
\text { primers oriented in opposing directions } \\
\text { across the integration site, then } \\
\text { sequenced by Sanger sequencing. }\end{array}$ & $\begin{array}{l}\text { Very accurate integration } \\
\text { site determination } \\
\text { Primers for amplification } \\
\text { designed for highly conserved } \\
\text { genomic regions }\end{array}$ & $\begin{array}{ll}\text { - } & \text { Very } \\
\text { low-throughput } \\
\text { detection of } \\
\text { integration site } \\
\text { - } \quad \text { Primers may not } \\
\text { recognize } \\
\text { all proviruses } \\
\text { Requires multiple } \\
\text { PCR steps }\end{array}$ \\
\hline
\end{tabular}


Table 2. Genome Amplification and Sequencing.

\begin{tabular}{|c|c|c|c|}
\hline Technique & Description & Advantages & Limitations \\
\hline $\begin{array}{l}\text { FLIPS (Full-length } \\
\text { individual proviral } \\
\text { sequencing) [15] }\end{array}$ & $\begin{array}{l}\text { An assay used to capture nearly } \\
\text { full-length genomes by two } \\
\text { non-overlapping, nested-PCR reactions } \\
\text { amplifying from the U5 region in the } 5^{\prime} \\
\text { and } 3^{\prime} \text { LTRs. PCR products are } \\
\text { sequenced by paired-end Illumina } \\
\text { sequencing using the Nextera library } \\
\text { preparation kit (Illumina). Reads are } \\
\text { mapped by de novo genome assembly. }\end{array}$ & $\begin{array}{l}\text { Captures nearly } \\
\text { full-length genomes } \\
\text { Can be used to } \\
\text { determine replication-competenc } \\
\text { - Can be used to } \\
\text { determine clonality }\end{array}$ & $\begin{array}{l}\text { Does not capture all } \\
\text { of the } \\
\text { LTR sequences }\end{array}$ \\
\hline $\begin{array}{l}\text { SCS Assay (single-cell } \\
\text { sequencing) [108] }\end{array}$ & $\begin{array}{l}\text { CD4+ T cells are FACS sorted from } \\
\text { HIV-infected patients into a 96-well } \\
\text { plate such that there is no more than } \\
\text { one cell in any one well. Once the cell in } \\
\text { each well is lysed, the DNA is } \\
\text { distributed from one well into 10. PCR } \\
\text { is used to amplify HIV DNA between } \\
\text { gag-pol, identified through } \\
\text { gel-electrophoresis, and sequenced. } \\
\text { Sequenced products can then be aligned } \\
\text { to a reference HIV genome. }\end{array}$ & $\begin{array}{l}\text { - Primers target highly } \\
\text { conserved regions and amplify } \\
\text { highly variable regions to } \\
\text { identify similarities between } \\
\text { HIV sequences } \\
\text { - Captures all proviral } \\
\text { sequences in a cell }\end{array}$ & $\begin{array}{l}\text { - Clonal sequences } \\
\text { will be } \\
\text { overestimated by } \\
\text { sequencing } \\
\text { partial genomes } \\
\text { Deletions and } \\
\text { mutations could be } \\
\text { found outside of the } \\
\text { amplified region } \\
\text { Does not capture } \\
\text { entire genomes }\end{array}$ \\
\hline $\begin{array}{c}\text { SPS/SGS } \\
\text { (Single-genome } \\
\text { (provirus) sequencing } \\
\text { and single genome } \\
\text { amplification) } \\
{[67,133,134] .}\end{array}$ & $\begin{array}{l}\text { Virions collected from the peripheral } \\
\text { blood or cultured media containing HIV } \\
\text { virion-producing cells are collected, } \\
\text { lysed, and converted to cDNA. The } \\
\text { cDNA is serially diluted and used for } \\
\text { qPCR with primer probe directed at pol } \\
\text { (SGS) or env (SGA). Once } \\
\text { HIV-containing samples are identified, } \\
\text { the cDNA is then subjected to PCR } \\
\text { amplification between gag-pol or env } \\
\text { and sequenced. }\end{array}$ & $\begin{array}{l}\text { - Some versions of the protocol } \\
\text { capture nearly full-length } \\
\text { genomes (nine ORFs) } \\
\text { Can be used to } \\
\text { determine replication-competenc } \\
\text { - Can be used to } \\
\text { determine clonality }\end{array}$ & $\begin{array}{l}\text { Not all versions of } \\
\text { the protocol } \\
\text { sequence } \\
\text { compete genomes } \\
\text { Whole HIV } \\
\text { genomes assembled } \\
\text { from multiple } \\
\text { PCR fragments } \\
\text { Sequencing } \\
\text { requires active } \\
\text { HIV expression }\end{array}$ \\
\hline
\end{tabular}

Table 3. Combined genome amplification and integration site analysis.

\begin{tabular}{|c|c|c|c|}
\hline Technique & Description & Advantages & Limitations \\
\hline $\begin{array}{c}\text { Matched integration } \\
\text { site and proviral } \\
\text { sequencing (MIP-Seq) } \\
{[115]}\end{array}$ & $\begin{array}{l}\text { Genomic DNA is isolated from } \\
\text { CD4+ T cells, quantified using } \\
\text { ddPCR for viral gag, and diluted to } \\
\text { single proviral genomes based on } \\
\text { ddPCR and Poisson distribution. } \\
\text { This is followed by multiple } \\
\text { displacement amplification (MDA) } \\
\text { and whole genome amplification } \\
\text { (WGA), generating 1,000-10,000 } \\
\text { copies of gDNA. Amplified gDNA } \\
\text { is divided such that some is used for } \\
\text { NFL sequencing [14] and some for } \\
\text { integration site analysis (ISLA; } \\
\text { Table 1; Figure 5) or other methods. }\end{array}$ & $\begin{array}{l}\text { Allows for the determination } \\
\text { of both the provirus } \\
\text { sequence and the integration } \\
\text { site from the same cell } \\
\text { Integration site analysis is } \\
\text { flexible depending on the } \\
\text { user-preferred technique } \\
\text { Combines techniques already } \\
\text { published in the literature for } \\
\text { both integration site and } \\
\text { genome sequencing }\end{array}$ & $\begin{array}{l}\text { - Involves many steps in order } \\
\text { to determine the integration } \\
\text { site and genome sequence } \\
\text { Relies on ddPCR for initial } \\
\text { quantification of DNA } \\
\text { - Must copy the entire human } \\
\text { genome, which can lead } \\
\text { to errors } \\
\text { - Sequencing techniques } \\
\text { introduce errors that can be } \\
\text { mistaken for real mutations }\end{array}$ \\
\hline $\begin{array}{l}\text { Multiple-displacement } \\
\text { amplification with } \\
\text { single-genome } \\
\text { sequencing } \\
\text { (MDA-SGS) [131] }\end{array}$ & $\begin{array}{l}\text { Genomic DNA is extracted from } \\
\text { PBMCs or other primary cells and } \\
\text { diluted across a 96-well plate. } \\
\text { Whole-gDNA is amplified in-well } \\
\text { using MDA. MDA wells are } \\
\text { screened for proviruses of interest } \\
\text { using SGS (subgenomic fragments) } \\
\text { from P6 through part of RT. Then } \\
\text { integration sites are determined } \\
\text { using modified TC-Seq (Table 1) } \\
\text { followed by NFL amplification } \\
\text { using Sanger sequencing or } \\
\text { PacBio sequencing. }\end{array}$ & $\begin{array}{l}\text { Allows for the determination } \\
\text { of both the provirus } \\
\text { sequence and the integration } \\
\text { site from the same cell } \\
\text { Combines techniques already } \\
\text { published in the literature }\end{array}$ & $\begin{array}{l}\text { - Involves many steps in order } \\
\text { to determine the integration } \\
\text { site and genome sequence } \\
\text { Must copy the entire human } \\
\text { genome, which can lead } \\
\text { to errors } \\
\text { - Sequencing techniques } \\
\text { introduce errors that can be } \\
\text { mistaken for real mutations } \\
\text { Custom pipeline needed to } \\
\text { determine intactness of } \\
\text { HIV genome }\end{array}$ \\
\hline
\end{tabular}


Table 4. Measuring the Latent Reservoir.

\begin{tabular}{|c|c|c|c|}
\hline Technique & Description & Advantages & Limitations \\
\hline $\begin{array}{l}\text { ddPCR (droplet digital } \\
\text { PCR) (reviewed [135]) }\end{array}$ & $\begin{array}{l}\text { Target molecules are emulsified into } \\
\text { thousands of nanoliter droplets and } \\
\text { amplified by PCR using a } \\
\text { primer-probe set. Droplets containing } \\
\text { HIV genomic material that fluoresces } \\
\text { above a certain threshold will be } \\
\text { considered positive. The ratio } \\
\text { between the positive and negative } \\
\text { droplets is used to calculate the } \\
\text { absolute number of starting molecules } \\
\text { using a Poisson distribution. }\end{array}$ & $\begin{array}{l}\text { - } \quad \text { Very accurate and versatile } \\
\text { - } \quad \text { both ve used to measure } \\
\text { - } \quad \begin{array}{l}\text { Does not need a } \\
\text { standard curve }\end{array} \\
\text { - } \quad \begin{array}{l}\text { Produces } \\
\text { absolute quantification } \\
\text { - } \\
\text { More reproducible than } \\
\text { standard qPCR }\end{array}\end{array}$ & $\begin{array}{l}\text { - Technically difficult and } \\
\text { thresholds are set by the user } \\
\text { - } \quad \text { High false-positive rate }\end{array}$ \\
\hline $\begin{array}{l}\text { IPDA (intact proviral } \\
\text { DNA assay) [136] }\end{array}$ & $\begin{array}{l}\text { Uses two amplicons covering the } \\
\text { packaging signal }(\psi) \text { and env region } \\
\text { and ddPCR to designate deleted } \\
\text { proviruses as defective. In parallel, } \\
\text { multiplex PCR is performed with two } \\
\text { unique primer-probe sets targeting } \psi \\
\text { and env with unique labeling probes } \\
\text { and measured by ddPCR. } \\
\text { Primer-probe sets amplify validated, } \\
\text { highly conserved regions of the } \\
\text { genome. Droplets are scored based on } \\
\text { expression of combinations of probe } \\
\text { fluorescent patterns. }\end{array}$ & $\begin{array}{l}\text { Primers are pre-designed } \\
\text { to recognize most } \\
\text { HIV sequences } \\
\text { Can quickly determine if a } \\
\text { provirus or RNA genome is } \\
\text { likely to be intact } \\
\text { or defective } \\
\text { Primer-probe sets can } \\
\text { determine the level of } \\
\text { intactness or defectiveness } \\
\text { of most proviral and } \\
\text { RNA genomes }\end{array}$ & $\begin{array}{l}\text { The entire viral genome is not } \\
\text { sequenced and can therefore } \\
\text { mis-classify HIV genomes } \\
\text { as intact } \\
\text { - Over-estimates the number of } \\
\text { intact viral genomes } \\
\text { - Requires ddPCR }\end{array}$ \\
\hline $\begin{array}{c}\text { TILDA(Tat/Rev } \\
\text { induced limiting } \\
\text { dilution assay) [137] }\end{array}$ & $\begin{array}{l}\text { CD4+ T cells are stimulated in vitro } \\
\text { (PMA and ionomycin) to maximally } \\
\text { produce tat/rev transcripts. Cells are } \\
\text { serially diluted as replicates. } \\
\text { Real-time PCR with primer-probe } \\
\text { pairs are used to quantify inducible } \\
\text { viral RNA. The frequency of cells with } \\
\text { inducible HIV RNA can then be } \\
\text { calculated from the number of } \\
\text { positive wells at each dilution by the } \\
\text { maximum likelihood method. }\end{array}$ & $\begin{array}{ll}\text { - } & \text { Measures latent reservoir } \\
\text { from total CD4+ T cells } \\
\text { - }\end{array}$ & $\begin{array}{l}\text { Only measures genomes } \\
\text { capable of being reactivated } \\
\text { - Not all latent infections can be } \\
\text { reactivated and measured [65] } \\
\text { - Assumes multiply spliced } \\
\text { genomes } \\
\text { indicate replication-competence }\end{array}$ \\
\hline $\begin{array}{c}\text { QVOA (quantitative } \\
\text { viral outgrowth assay) } \\
{[138,139]}\end{array}$ & $\begin{array}{l}\text { Culture method to quantify the } \\
\text { replication-competent viral reservoir. } \\
\text { HIV(+) donor rCD4+ T cells are } \\
\text { cultured with irradiated PBMCs and } \\
\text { CD4+ T cells from an HIV(-) donor } \\
\text { and stimulated (PHA; IL-2). } \\
\text { Replication -competent virus can } \\
\text { spread to HIV(-) CD4+ T cells, } \\
\text { amplifying the infection, allowing } \\
\text { detection and quantification of } \\
\text { viral outgrowth. }\end{array}$ & 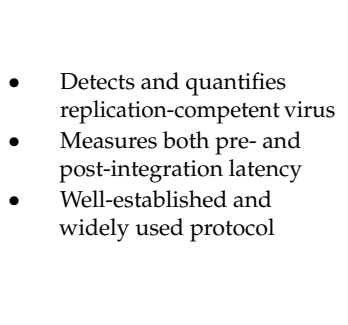 & $\begin{array}{l}\text { - Only measures genomes } \\
\text { capable of being reactivated } \\
\text { - Not all latent infections can be } \\
\text { reactivated and measured } \\
\text { - Underestimates the size of the } \\
\text { latent reservoir } \\
\text { - } \quad \begin{array}{l}\text { Requires allogenic donor } \\
\text { lymphoblasts for } \\
\text { spreading infection }\end{array}\end{array}$ \\
\hline $\begin{array}{l}\text { mQVOA (Modified } \\
\text { quantitative viral } \\
\text { outgrowth assay) [140] }\end{array}$ & $\begin{array}{l}\text { A more sensitive adaptation of the } \\
\text { gold-standard assay; CD4+ T cells } \\
\text { from patients are serially diluted and } \\
\text { stimulated ( } \alpha \text { CD3/CD28 antibodies). } \\
\text { MOLT-4/CCR5 cells are co-cultured } \\
\text { with the primary cells. HIV RNA is } \\
\text { extracted, and RT-qPCR is performed } \\
\text { to amplify pol. The number of wells } \\
\text { positive for HIV RNA at each dilution } \\
\text { level are used to determine the } \\
\text { infection frequency by maximum } \\
\text { likelihood estimate. }\end{array}$ & $\begin{array}{l}\text { Does not require allogenic } \\
\text { donor lymphoblasts for } \\
\text { spreading infection } \\
\text { qPCR used for quantitative } \\
\text { measurement of the viral } \\
\text { RNA products }\end{array}$ & $\begin{array}{l}\text { - Only measures genomes } \\
\text { capable of being reactivated } \\
\text { Not all latent infections can be } \\
\text { reactivated and measured } \\
\text { - Underestimates the size of the } \\
\text { latent reservoir }\end{array}$ \\
\hline $\begin{array}{c}\text { dQVOA } \\
\text { (differentiation culture } \\
\text { quantitative viral } \\
\text { Outgrowth assay) [141] }\end{array}$ & $\begin{array}{l}\text { Measures the impact of } \mathrm{T}_{\mathrm{EM}} \\
\text { differentiation on induction and } \\
\text { outgrowth of replication-competent } \\
\text { HIV. rCD4+ T cells from patients are } \\
\text { activated through culture with a } \\
\text { differentiation cytokine cocktails to } \\
\text { drive cells towards the } \mathrm{T}_{\mathrm{EM}} \text { terminally } \\
\text { differentiated subset. Cells are } \\
\text { distributed at limiting dilutions and } \\
\text { cultured in differentiation cytokines, } \\
\text { then activated. Titer measured by } \\
\text { p24 ELISA. }\end{array}$ & $\begin{array}{l}\text { - Higher viral titer induction } \\
\text { rate compared to QVOA } \\
\text { - } \quad \begin{array}{l}\text { Higher frequency of latent } \\
\text { cell activation over QVOA }\end{array} \\
\text { Does not require allogenic } \\
\text { donor lymphoblasts for } \\
\text { spreading infection }\end{array}$ & $\begin{array}{l}\text { Only measures genomes } \\
\text { capable of being reactivated } \\
\text { Not all latent infections can be } \\
\text { reactivated and measured } \\
\text { - Underestimates the size of the } \\
\text { latent reservoir }\end{array}$ \\
\hline
\end{tabular}


Key:

LTRs $\square$ HIV ORFs Human Chromosome $\longrightarrow$ Primer $\leftarrow-$ New Synthesis

Step 1. Linear extension PCR

5'LTR 3'LTR env nef

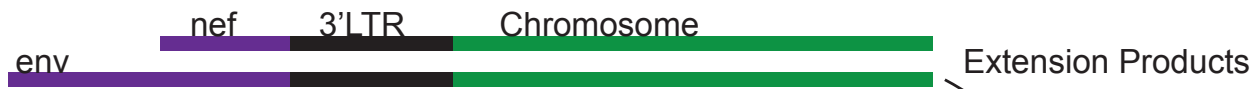

Step 2. Random decamer-U5 \& U5 only primer binding

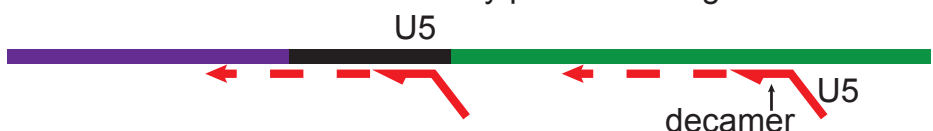

Step 3. Synthesis of reverse strand \& reverse-compliment of decamer-U5 primer

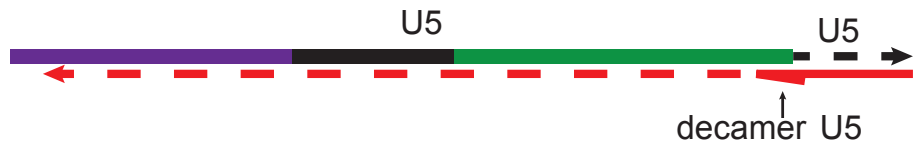

Step 4. Denature, then loop formation through U5 annealing

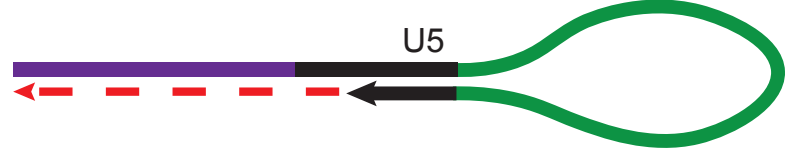

Step 5. Extension from U5 primer; Complete loop

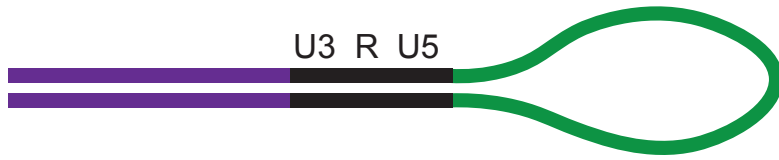

Step 6. Nested PCR \& amplicon generation for sequencing integration site

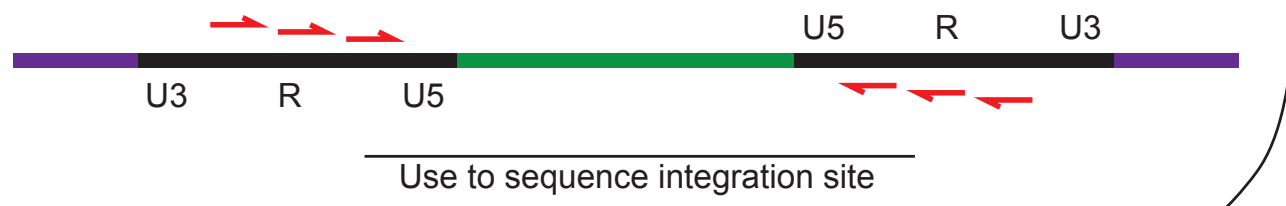

Step 7. Amplify initial linear PCR product between env and human chromosome
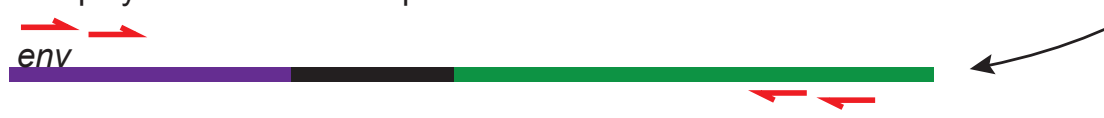

Use for sequencing

Figure 5. Integration site loop amplification (ISLA). Modified from [76]. Black segments represent long-terminal repeat (LTR) regions; purple, HIV open reading frames (ORFs); green, human chromosomal DNA.

\section{Conclusions}

HIV targets cells based on cell surface expression of CD4 and one of two co-receptors. Many of the infected cells die from infection, but a small fraction of these cells survives and become quiescent, forming the latent viral reservoir. The reservoir is primarily memory CD4+ T cells and hematopoietic stem and progenitor cells. Recently, proliferation of latently-infected cells was identified as a means of maintaining and expanding the viral reservoir through monitoring the unique integration site of each provirus or sequencing full and partial genomes and inferring clonality. Both CD4+ T cells and HSPCs are long-lived and have the potential to proliferate and differentiate. For example, differentiation of an infected HSPC will ensure all daughter cells carry the same provirus in the same genomic location 
with them, expanding the viral reservoir. Similarly, an infected T cell that proliferates will also carry the provirus into every daughter cell. Some latent clones can expand to significant numbers. The large majority of proliferating latently-infected cells contain a defective provirus; however, a significant minority of clones contain replication-competent provirus. Clonally expanded cells are capable of reactivating and spreading virus, posing a major obstacle to curing HIV.

The impact of proliferation on the viral reservoir is a new and exciting area of research, but there are many outstanding questions to be addressed. New $\mathrm{T}$ cell subsets are now implicated in maintenance of the reservoir, particularly $\mathrm{T}_{\mathrm{N}}$ and $\mathrm{T}_{\mathrm{SCM}}$. More studies are needed to confirm the relative impact of these $\mathrm{T}$ cell subsets as well as the proliferative capacity of $\mathrm{T}_{\mathrm{N}}$ and $\mathrm{T}_{\mathrm{SCM}}$ cells. Similarly, several studies have suggested an important role for latently infected HSPCs, but questions remain regarding the extent of their contribution to the HIV reservoir.

Future studies focused on better understanding the role of integration site selection and its effect on the selective amplification of some HIV proviruses are needed to assess the contribution of host genes to the maintenance of the HIV reservoir. Thus far, studies have provided complex and sometimes contradictory evidence about the relative importance of integration site selection on reservoir maintenance.

Given the potential impact of HIV integration on the human genome, the fact that cancer has not yet been associated with HIV infection is remarkable. However, ART has only been available for at most 40 years and it may be too early to tell whether cancers related to HIV will emerge in the future.

Sex-biases in our understanding of the HIV reservoir must also be addressed. Many studies conducted in the developed world are heavily biased towards male participants, which is concerning given the large body of evidence that suggests there are known sex-specific differences for disease progression and response to therapies (reviewed [80]).

Finally, although much is already known about clonality, integration site, and replication competency in maintaining the viral reservoir (as discussed in this review) there is still much to be discovered. Given the amount of heterogeneity and the low frequency of intact proviral genomes, high-throughput methods are needed to achieve the goals outlined in this review so that future treatment strategies can be effective at eliminating all viral reservoirs.

Author Contributions: Conceptualization, M.C.V. and K.L.C.; writing-original draft preparation, M.C.V.; writing-review and editing, M.C.V. and K.L.C.; visualization, M.C.V. All authors have read and agreed to the published version of the manuscript.

Funding: This research was funded by NIH R01AI148084 to K.L.C., NIH T32-GM007315 to M.C.V., and the University of Michigan Rackham Regents Fellowship to M.C.V.

Acknowledgments: Many thanks to members of the Collins Lab for their feedback and review, especially Valeri Terry, Mark Painter, and Jay Lubow. Thanks also to Thomas Zaikos for help with the figures.

Conflicts of Interest: The authors declare no conflicts of interest.

\section{Abbreviations}

PBMC

BMMC

HSPC

HDI

TCR

RT

pMHCII

APC

ORF

ELISA

rCD4

MOLT-4/CCR5 peripheral blood mononuclear cell

bone marrow mononuclear cell

hematopoietic stem and progenitor cell

histone deacetylase inhibitor

$\mathrm{T}$ cell antigen receptor

reverse transcriptase

peptide-bound major histocompatibility complex II

antigen presenting cell

open reading frame

enzyme-linked immunosorbent assay

resting $\mathrm{CD} 4$

cells from the CCR5-expressing T cell line MOLT-4 


$\begin{array}{ll}\text { FACS } & \text { Fluorescence Activated Cell Sorting } \\ \mathrm{T}_{\mathrm{H}} & \text { T helper cell } \\ \mathrm{T}_{\mathrm{EM}} & \text { T effector memory } \\ \mathrm{T}_{\mathrm{CM}} & \text { T central memory } \\ \mathrm{T}_{\mathrm{TM}} & \mathrm{T} \text { transitional memory } \\ \mathrm{T}_{\mathrm{SCM}} & \text { T stem cell memory } \\ \mathrm{ART} & \text { antiretroviral therapy } \\ \text { PV } & \text { peripheral virus } \\ \text { MSD } & \text { major splice donor site } \\ \text { LTR } & \text { long terminal repeat } \\ \text { NFL } & \text { near full length. }\end{array}$

\section{References}

1. Chun, T.-W.; Finzi, D.; Margolick, J.; Chadwick, K.; Schwartz, D.; Siliciano, R.F. In Vivo fate of HIV-1-infected T cells: Quantitative analysis of the transition to stable latency. Nat. Med. 1995, 1, 1284-1290. [CrossRef] [PubMed]

2. Finzi, D.; Hermankova, M.; Pierson, T.; Carruth, L.; Buck, C.; Chaisson, R.; Quinn, T.; Chadwick, K.; Margolick, J.; Brookmeyer, R.; et al. Identification of a reservoir for HIV-1 in patients on highly active antiretroviral therapy. Science 1997, 278, 1295-1300. [CrossRef] [PubMed]

3. Finzi, D.; Blankson, J.; Siliciano, J.; Margolick, J.; Chadwick, K.; Pierson, T.; Smith, K.; Lisziewicz, J.; Lori, F.; Flexner, C.; et al. Latent infection of CD4+ T cells provides a mechanism for lifelong persistence of HIV-1, even in patients on effective combination therapy. Nat. Med. 1999, 5, 512-517. [CrossRef] [PubMed]

4. Siliciano, J.; Kajdas, J.; Finzi, D.; Quinn, T.; Chadwick, K.; Margolick, J.; Kovacs, C.; Gange, S.; Siliciano, R.F. Long-term follow-up studies confirm the stability of the latent reservoir for HIV-1 in resting CD4+ T cells. Nat. Med. 2003, 9, 727-728. [CrossRef] [PubMed]

5. Menéndez-Arias, L. Mutation rates and intrinsic fidelity of retroviral reverse transcriptases. Viruses 2009, 1, 1137-1165. [CrossRef] [PubMed]

6. $\quad$ Bruner, K.; Murray, A.; Pollack, R.; Soliman, M.; Laskey, S.; Capoferri, A.; Lai, J.; Strain, M.; Lada, S.; Hoh, R.; et al. Defective proviruses rapidly accumulate during acute HIV-1 infection. Nat. Med. 2016, 22, 1043-1049. [CrossRef] [PubMed]

7. Cohn, L.; Silva, I.; Oliveira, T.; Rosales, R.; Parrish, E.; Learn, G.; Hahn, B.; Czartoski, J.; McElrath, M.; Lehmann, C.; et al. HIV-1 integration landscape during latent and active infection. Cell 2015, 160, 420-432. [CrossRef]

8. Simonetti, F.; Sobolewski, M.; Fyne, E.; Shao, W.; Spindler, J.; Hattori, J.; Anderson, E.; Watters, S.; Hill, S.; $\mathrm{Wu}, \mathrm{X}$; et al. Clonally expanded CD4+ T cells can produce infectious HIV-1 In Vivo. Proc. Natl. Acad. Sci. USA 2016, 113, 1883-1888. [CrossRef]

9. Reeves, D.; Duke, E.; Wagner, T.; Palmer, S.; Spivak, A.; Schiffer, J.T. A majority of HIV persistence during antiretroviral therapy is due to infected cell proliferation. Nat. Commun. 2018, 9, 4811. [CrossRef]

10. Wagner, T.; McKernan, J.; Tobin, N.; Tapia, K.; Mullins, J.; Frenkel, L.M. An increasing proportion of monotypic HIV-1 dna sequences during antiretroviral treatment suggests proliferation of HIV-Infected Cells. J. Virol. 2013, 87, 1770-1778. [CrossRef]

11. Zaikos, T.; Terry, V.; Sebastian Kettinger, N.; Lubow, J.; Painter, M.; Virgilio, M.; Neevel, A.; Taschuk, F.; Onafuwa-Nuga, A.; McNamara, L.; et al. Hematopoietic stem and progenitor cells are a distinct hiv reservoir that contributes to persistent viremia in suppressed patients. Cell Rep. 2018, 25, 3759-3773. [CrossRef] [PubMed]

12. Sebastian, N.; Zaikos, T.; Terry, V.; Taschuk, F.; McNamara, L.; Onafuwa-Nuga, A.; Yucha, R.; Signer, R.A.J.; Riddell, J., IV; Bixby, D.; et al. CD4 is expressed on a heterogeneous subset of hematopoietic progenitors, which persistently harbor CXCR4 and CCR5-tropic HIV proviral genomes In Vivo. PLoS Pathog. 2017, 13, e1006509. [CrossRef] [PubMed]

13. Bailey, J.; Sedaghat, A.; Kieffer, T.; Brennan, T.; Lee, P.; Wind-Rotolo, M.; Haggerty, C.; Kamireddi, A.; Liu, Y.; Lee, J.; et al. Residual human immunodeficiency virus type 1 viremia in some patients on antiretroviral 
therapy is dominated by a small number of invariant clones rarely found in circulating CD4+ T cells. J. Virol. 2006, 80, 6441-6457. [CrossRef] [PubMed]

14. Lee, G.; Orlova-Fink, N.; Einkauf, K.; Chowdhury, F.; Sun, X.; Harrington, S.; Kuo, H.-H.; Hua, S.; Chen, H.-R.; Ouyang, Z.; et al. Clonal expansion of genome-intact HIV-1 in functionally polarized Th1 CD4+ T cells. J. Clin. Invest. 2017, 127, 2689-2696. [CrossRef]

15. Hiener, B.; Horsburgh, B.; Eden, J.-S.; Barton, K.; Schlub, T.; Lee, E.; von Stockenstrom, S.; Odevall, L.; Milush, J.; Liegler, T.; et al. Identification of genetically intact HIV-1 proviruses in specific CD4+ T cells from effectively treated participants. Cell Rep. 2017, 21, 813-822. [CrossRef]

16. Carter, C.; Onafuwa-Nuga, A.; McNamara, L.; Riddell, J.; Bixby, D.; Savona, M.; Collins, K.L. HIV-1 infects multipotent progenitor cells causing cell death and establishing latent cellular reservoirs. Nat. Med. 2010, 16, 446-451. [CrossRef]

17. Perelson, A.; Essunger, P.; Cao, Y.; Vesanen, M.; Hurley, A.; Saksela, K.; Markowitz, M.; Ho, D.D. Decay characteristics of HIV-1-infected compartments during combination therapy. Nature 1997, 387, 188-191. [CrossRef]

18. Ho, D.; Neumann, U.; Perelson, A.; Chen, W.; Leonardt, J.; Markowitz, M. Rapid turnover of plasma virions and CD4 lymphocytes in HIV-1 infection. Nature 1995, 373, 123-126. [CrossRef]

19. Chun, T.W.; Davey, R.T., Jr.; Ostrowski, M.; Justement, J.S.; Engel, D.; Mullins, J.I.; Fauci, A.S. Relationship between pre-existing viral reservoirs and the re-emergence of plasma viremia after discontinuation of highly active anti-retroviral therapy. Nat. Med. 2000, 6, 757-761. [CrossRef]

20. Chun, T.-W.; Stuyver, L.; Mizell, S.; Ehler, L.; Mican, J.A.M.; Baseler, M.; Lloyd, A.; Nowak, M.; Fauci, A.S. Presence of an inducible HIV-1 latent reservoir during highly active antiretroviral therapy. Proc. Natl. Acad. Sci. USA 1997, 94, 13193-13197. [CrossRef]

21. Buzon, M.; Sun, H.; Li, C.; Shaw, A.; Seiss, K.; Ouyang, Z.; Martin-Gayo, E.; Leng, J.; Henrich, T.; Li, J.; et al. HIV-1 persistence in CD4+ T cells with stem cell-like properties. Nat. Med. 2014, 20, 139-142. [CrossRef]

22. McNamara, L.; Ganesh, J.; Collins, K.L. Latent HIV-1 infection occurs in multiple subsets of hematopoietic progenitor cells and is reversed by NF-KB activation. J. Virol. 2012, 86, 9337-9350. [CrossRef]

23. Berger, E.; Murphy, P.; Farber, J.M. Chemokine receptors AS HIV-1 coreceptors: Roles in viral entry, tropism, and disease. Annu. Rev. Immunol. 1999, 17, 657-700. [CrossRef]

24. Alkhatib, G. The biology of CCR5 and CXCR4. Curr. Opin. HIV AIDS 2009, 4, 96. [CrossRef]

25. Scarlatti, G.; Tresoldi, E.; Björndal, Å.; Fredriksson, R.; Colognesi, C.; Kui Deng, H.; Malnati, M.; Plebani, A.; Siccardi, A.; Littman, D.; et al. In Vivo evolution of HIV-1 co-receptor usage and sensitivity to chemokine-mediated suppression. Nat. Med. 1997, 3, 1259-1265. [CrossRef]

26. Connor, R.; Sheridan, K.; Ceradini, D.; Choe, S.; Landau, N.R. Change in coreceptor use correlates with disease progression in HIV-1-infected individuals. J. Exp. Med. 1997, 185, 621-628. [CrossRef]

27. Fouchier, R.A.M.; Meyaard, L.; Brouwer, M.; Hovenkamp, E.; Schuitemaker, H. Broader tropism and higher cytopathicity for CD4+T cells of a syncytium-inducing compared to a non-syncytium-inducing HIV-1 isolate as a mechanism for accelerated CD4+T cell declinein vivo. Virology 1996, 219, 87-95. [CrossRef]

28. Koot, M.; Van Leeuwen, R.; De Goede, R.E.Y.; Keet, I.P.M.; Danner, S.; Schattenkerk, J.E.; Schuitemaker, H. Conversion Rate towards a Syncytium-Inducing (SI) phenotype during different stages of human immunodeficiency virus type 1 infection and prognostic value of, S.I. phenotype for survival after AIDS diagnosis. J. Infect. Dis. 1999, 179, 254-258. [CrossRef]

29. Biti, R.; Ffrench, R.; Young, J.; Bennetts, B.; Stewart, G.; Liang, T. HIV-1 infection in an individual homozygous for the CCR5 deletion allele. Nat. Med. 1997, 3, 252-253. [CrossRef]

30. Dean, M.; Carrington, M.; Winkler, C.; Huttley, G.; Smith, M.; Allikmets, R.; Goedert, J.; Buchbinder, S.; Vittinghoff, E.; Gomperts, E.; et al. Genetic restriction of HIV-1 infection and progression to AIDS by a deletion allele of the CKR5 structural gene. Science 1996, 273, 1856-1862. [CrossRef]

31. Liu, R.; Paxton, W.; Choe, S.; Ceradini, D.; Martin, S.; Horuk, R.; MacDonald, M.; Stuhlmann, H.; Koup, R.; Landau, N.R. Homozygous defect in HIV-1 coreceptor accounts for resistance of some multiply-exposed individuals to HIV-1 infection. Cell 1996, 86, 367-377. [CrossRef]

32. Samson, M.; Libert, F.; Doranz, B.; Rucker, J.; Liesnard, C.; Farber, C.-M.; Saragosti, S.; Lapouméroulie, C.; Cognaux, J.; Forceille, C.; et al. Resistance to HIV-1 infection in Caucasian individuals bearing mutant alleles of the CCR-5 chemokine receptor gene. Nature 1996, 382, 722-725. [CrossRef] [PubMed] 
33. Naif, H.; Cunningham, A.; Alali, M.; Li, S.; Nasr, N.; Buhler, M.; Schols, D.; de Clercq, E.; Stewart, G. A human immunodeficiency virus type 1 isolate from an infected person homozygous for CCR5Delta32 exhibits dual tropism by infecting macrophages and MT2 cells via CXCR4. J. Virol. 2002, 76, 3114-3124. [CrossRef] [PubMed]

34. Gorry, P.; Zhang, C.; Wu, S.; Kunstman, K.; Trachtenberg, E.; Phair, J.; Wolinsky, S.; Gabuzda, D. Persistence of dual-tropic HIV-1 in an individual homozygous for the CCR5 $\Delta 32$ allele. Lancet 2002, 359, 1832-1834. [CrossRef]

35. Carter, C.; McNamara, L.; Onafuwa-Nuga, A.; Shackleton, M.; Riddell, J.; Bixby, D.; Savona, M.; Morrison, S.; Collins, K.L. HIV-1 utilizes the CXCR4 chemokine receptor to infect multipotent hematopoietic stem and progenitor cells. Cell Host Microbe 2011, 9, 223-234. [CrossRef] [PubMed]

36. Nixon, C.; Vatakis, D.; Reichelderfer, S.; Dixit, D.; Kim, S.; Uittenbogaart, C.; Zack, J.A. HIV-1 infection of hematopoietic progenitor cells In Vivo in humanized mice. Blood 2013, 122, 2195-2204. [CrossRef]

37. Bonecchi, R.; Bianchi, G.; Bordignon, P.; D'Ambrosio, D.; Lang, R.; Borsatti, A.; Sozzani, S.; Allavena, P.; Gray, P.; Mantovani, A.; et al. Differential expression of chemokine receptors and chemotactic responsiveness of type 1 T helper cells (Th1s) and Th2s. J. Exp. Med. 1998, 187, 129-134. [CrossRef]

38. Han, Y.; Lassen, K.; Monie, D.; Sedaghat, A.; Shimoji, S.; Liu, X.; Pierson, T.; Margolick, J.; Siliciano, R.; Siliciano, J.D. Resting CD4+ T cells from human immunodeficiency virus type 1 (HIV-1)-infected individuals carry integrated HIV-1 genomes within actively transcribed host genes. J. Virol. 2004, 78, 6122-6133. [CrossRef]

39. Pierson, T.; Hoffman, T.; Blankson, J.; Finzi, D.; Chadwick, K.; Margolick, J.; Buck, C.; Siliciano, J.; Doms, R.; Siliciano, R.F. Characterization of chemokine receptor utilization of viruses in the latent reservoir for human immunodeficiency virus type 1. J. Virol. 2000, 74, 7824-7833. [CrossRef]

40. Rabin, R.; Park, M.; Fang, L.; Swofford, R.; Stephany, D.; Farber, J.M. The chemokine receptor CCR8 is preferentially expressed in Th2 but not Th1 cells. J. Immunol. 1999, 162, 3840-3850.

41. Jacobsen, S.E.W.; Nerlov, C. Haematopoiesis in the era of advanced single-cell technologies. Nat. Cell Biol. 2019, 21, 2-8. [CrossRef] [PubMed]

42. Zhang, Y.; Gao, S.; Xia, J.; Liu, F. Special issue: Stem cell biology hematopoietic hierarchy-an updated roadmap. Trends Cell Biol. 2018, 28, 976-986. [CrossRef] [PubMed]

43. Nakamura-Ishizu, A.; Takizawa, H.; Suda, T. The analysis, roles and regulation of quiescence in hematopoietic stem cells. Development 2014, 141, 4656-4666. [CrossRef] [PubMed]

44. Painter, M.; Zaikos, T.; Collins, K.L. Quiescence promotes latent hiv infection and resistance to reactivation from latency with histone deacetylase inhibitors. J. Virol. 2017, 91, e01080-17. [CrossRef]

45. Liudahl, S.; Coussens, L.M. To help or to harm: Dynamic roles of CD4+ T helper cells in solid tumor microenvironments. In Immunology, Volume 1, Immunotoxicology, Immunopathology, and Immunotherapy; Academic Press: Cambridge, MA, USA, 2018; pp. 97-116.

46. Pepper, M.; Jenkins, M.K. Origins of CD4+ effector and central memory T cells. Nat. Immunol. 2011, 12, 467-471. [CrossRef]

47. Shan, L.; Deng, K.; Gao, H.; Xing, S.; Capoferri, A.; Durand, C.; Rabi, S.; Laird, G.; Kim, M.; Hosmane, N.; et al. Transcriptional reprogramming during effector-to-memory transition renders $\mathrm{CD} 4+\mathrm{T}$ cells permissive for latent HIV-1 infection. Immunity 2017, 47, 766-775. [CrossRef]

48. Mahnke, Y.; Brodie, T.; Sallusto, F.; Roederer, M.; Lugli, E. The who's who of T-cell differentiation: Human memory T-cell subsets. Eur. J. Immunol. 2013, 43, 2797-2809. [CrossRef]

49. Sallusto, F.; Geginat, J.; Lanzavecchia, A. Central memory and effector memory T cell subsets: Function, generation, and maintenance. Annu. Rev. Immunol. 2004, 22, 745-763. [CrossRef]

50. Macallan, D.; Wallace, D.; Zhang, Y.; De Lara, C.; Worth, A.; Ghattas, H.; Griffin, G.; Beverley, P.C.L.; Tough, D.F. Rapid turnover of effector-memory CD4(+) T cells in healthy humans. J. Exp. Med. 2004, 200, 255-260. [CrossRef]

51. Den Braber, I.; Mugwagwa, T.; Vrisekoop, N.; Westera, L.; Mö, R.; Bregje De Boer, A.; Willems, N.; Schrijver, E.H.R.; Spierenburg, G.; Gaiser, K.; et al. Maintenance of peripheral naive T cells is sustained by thymus output in mice but not humans. Immunity 2012, 36, 288-297. [CrossRef]

52. Riou, C.; Yassine-Diab, B.; Van grevenynghe, J.; Somogyi, R.; Greller, L.; Gagnon, D.; Gimmig, S.; Wilkinson, P.; Shi, Y.; Cameron, M.; et al. Convergence of TCR and cytokine signaling leads to FOXO3a phosphorylation and drives the survival of CD4+ central memory T cells. J. Exp. Med. 2007, 204, 79-91. [CrossRef] [PubMed] 
53. Van Grevenynghe, J.; Procopio, F.; He, Z.; Chomont, N.; Riou, C.; Zhang, Y.; Gimmig, S.; Boucher, G.; Wilkinson, P.; Shi, Y.; et al. Transcription factor FOXO3a controls the persistence of memory CD4+ T cells during HIV infection. Nat. Med. 2008, 14, 266-274. [CrossRef] [PubMed]

54. Pekalski, M.; Ferreira, R.; Coulson, R.M.R.; Cutler, A.; Guo, H.; Smyth, D.; Downes, K.; Dendrou, C.; Castro Dopico, X.; Esposito, L.; et al. postthymic expansion in human CD4 naive T cells defined by expression of functional high-affinity IL-2 receptors. J. Immunol. 2013, 190, 2554-2566. [CrossRef] [PubMed]

55. Silva, S.; Albuquerque, A.; Matoso, P.; Charmeteau-de-Muylder, B.; Cheynier, R.; Ligeiro, D.; Abecasis, M.; Anjos, R.; Barata, J.; Victorino, R.M.M.; et al. IL-7-induced proliferation of human naive CD4 T-cells relies on continued thymic activity. Front. Immunol. 2017, 8, 20. [CrossRef]

56. Vandergeeten, C.; Fromentin, R.; DaFonseca, S.; Lawani, M.; Sereti, I.; Lederman, M.; Ramgopal, M.; Routy, J.-P.; Sékaly, R.-P.; Chomont, N. Interleukin-7 promotes HIV persistence during antiretroviral therapy. Blood 2013, 121, 4321-4329. [CrossRef]

57. Wang, Z.; Gurule, E.; Brennan, T.; Gerold, J.; Kwon, K.; Hosmane, N.; Kumar, M.; Beg, S.; Capoferri, A.; Ray, S.; et al. Expanded cellular clones carrying replication-competent HIV-1 persist, wax, and wane. Proc. Natl. Acad. Sci. USA 2018, 115, E2575-E2584. [CrossRef]

58. Bosque, A.; Famiglietti, M.; Weyrich, A.; Goulston, C.; Planelles, V. homeostatic proliferation fails to efficiently reactivate HIV-1 latently infected central memory CD4+ T cells. PLoS Pathog. 2011, 7, e1002288. [CrossRef]

59. Boyman, O.; Sprent, J. The role of interleukin-2 during homeostasis and activation of the immune system. Nat. Rev. Immunol. 2012, 12, 180-190. [CrossRef]

60. Dobrowolski, C.; Valadkhan, S.; Graham, A.; Shukla, M.; Ciuffi, A.; Telenti, A.; Karn, J. Entry of polarized effector cells into quiescence forces HIV latency. MBio 2019, 10, e00337-19. [CrossRef]

61. Archin, N.; Liberty, A.; Kashuba, A.; Choudhary, S.; Kuruc, J.; Crooks, A.; Parker, D.; Anderson, E.; Kearney, M.; Strain, M.; et al. Administration of vorinostat disrupts HIV-1 latency in patients on antiretroviral therapy. Nature 2012, 487, 482-485. [CrossRef]

62. Chomont, N.; El-Far, M.; Ancuta, P.; Trautmann, L.; Procopio, F.; Yassine-Diab, B.; Boucher, G.; Boulassel, M.-R.; Ghattas, G.; Brenchley, J.; et al. HIV reservoir size and persistence are driven by T cell survival and homeostatic proliferation. Nat. Med. 2009, 15, 893-900. [CrossRef] [PubMed]

63. Gattinoni, L.; Lugli, E.; Ji, Y.; Pos, Z.; Paulos, C.; Quigley, M.; Almeida, J.; Gostick, E.; Yu, Z.; Carpenito, C.; et al. A human memory T cell subset with stem cell-like properties. Nat. Med. 2011, 17, 1290-1297. [CrossRef]

64. Anderson, E.; Maldarelli, F. The role of integration and clonal expansion in HIV infection: Live long and prosper. Retrovirology 2018, 15, 71. [CrossRef] [PubMed]

65. Ho, Y.-C.; Shan, L.; Hosmane, N.; Wang, J.; Laskey, S.; Rosenbloom, D.I.S.; Lai, J.; Blankson, J.; Siliciano, J.; Siliciano, R.F. Replication-competent noninduced proviruses in the latent reservoir increase barrier to HIV-1 cure. Cell 2013, 155, 540-551. [CrossRef] [PubMed]

66. Hosmane, N.; Kwon, K.; Bruner, K.; Capoferri, A.; Beg, S.; Rosenbloom, D.I.S.; Keele, B.; Ho, Y.-C.; Siliciano, J.; Siliciano, R.F. Proliferation of latently infected CD4+ T cells carrying replication-competent HIV-1, Potential role in latent reservoir dynamics. J. Exp. Med. 2017, 214, 959-972. [CrossRef] [PubMed]

67. Bui, J.; Sobolewski, M.; Keele, B.; Spindler, J.; Musick, A.; Wiegand, A.; Luke, B.; Shao, W.; Hughes, S.; Coffin, J.; et al. Proviruses with identical sequences comprise a large fraction of the replication-competent HIV reservoir. PLoS Pathog. 2017, 13, e1006283. [CrossRef] [PubMed]

68. Kim, V.; Mitrophanous, K.; Kingsman, S.; Kingsman, A.J. Minimal requirement for a lentivirus vector based on human immunodeficiency virus type 1. J. Virol. 1998, 72, 811-816. [CrossRef]

69. Symons, J.; Cameron, P.; Lewin, S.R. HIV integration sites and implications for maintenance of the reservoir. Curr. Opin. HIV AIDS 2018, 13, 152-159. [CrossRef]

70. Pinzone, M.; Vanbelzen, D.; Weissman, S.; Bertuccio, M.; Cannon, L.; Venanzi-Rullo, E.; Migueles, S.; Jones, R.; Mota, T.; Joseph, S.; et al. Longitudinal HIV sequencing reveals reservoir expression leading to decay which is obscured by clonal expansion. Nat Commun. 2019, 10, 728. [CrossRef]

71. Purcell, D.; Martin, M.A. Alternative splicing of human immunodeficiency virus type 1 mRNA modulates viral protein expression, replication, and infectivity. J. Virol. 1993, 67, 6365-6378. [CrossRef]

72. Schwartz, S.; Felber, B.; Benko, D.; Fenyö, E.; Pavlakis, G.N. Cloning and functional analysis of multiply spliced mRNA species of human immunodeficiency virus type 1. J. Virol. 1990, 64, 2519-2529. [CrossRef] [PubMed] 
73. Reyon, D.; Khayter, C.; Regan, M.; Keith Joung, J.; Sander, J.D. Engineering designer transcription activator-like effector nucleases (TALENs) by REAL or REAL-Fast assembly. Curr. Protoc. Mol. Biol. 2012, 100, 12-15. [CrossRef] [PubMed]

74. Ocwieja, K.; Sherrill-Mix, S.; Mukherjee, R.; Custers-Allen, R.; David, P.; Brown, M.; Wang, S.; Link, D.; Olson, J.; Travers, K.; et al. Dynamic regulation of HIV-1 mRNA populations analyzed by single-molecule enrichment and long-read sequencing. Nucleic Acids Res. 2012, 40, 10345-10355. [CrossRef] [PubMed]

75. Cesana, D.; Santoni de Sio, F.; Rudilosso, L.; Gallina, P.; Calabria, A.; Beretta, S.; Merelli, I.; Bruzzesi, E.; Passerini, L.; Nozza, S.; et al. HIV-1-mediated insertional activation of STAT5B and BACH2 trigger viral reservoir in T regulatory cells. Nat. Commun. 2017, 8, 498. [CrossRef]

76. Wagner, T.; McLaughlin, S.; Garg, K.; Cheung, C.Y.K.; Larsen, B.; Styrchak, S.; Huang, H.; Edlefsen, P.; Mullins, J.; Frenkel, L.M. Proliferation of cells with HIV integrated into cancer genes contributes to persistent infection. Science 2014, 345, 570-573. [CrossRef]

77. Coffin, J.; Wells, D.; Zerbato, J.; Kuruc, J.; Guo, S.; Luke, B.; Eron, J.; Bale, M.; Spindler, J.; Simonetti, F.; et al. Clones of infected cells arise early in HIV-infected individuals. JCI Insight 2019, 4. [CrossRef]

78. Scully, E.; Gandhi, M.; Johnston, R.; Hoh, R.; Lockhart, A.; Dobrowolski, C.; Pagliuzza, A.; Milush, J.; Baker, C.; Girling, V.; et al. Sex-based differences in human immunodeficiency virus type 1 reservoir activity and residual immune activation. J. Infect. Dis. 2019, 219, 1084-1094. [CrossRef]

79. Das, B.; Dobrowolski, C.; Luttge, B.; Valadkhan, S.; Chomont, N.; Johnston, R.; Bacchetti, P.; Hoh, R.; Gandhi, M.; Deeks, S.; et al. Estrogen receptor-1 is a key regulator of HIV-1 latency that imparts gender-specific restrictions on the latent reservoir. Proc. Natl. Acad. Sci. USA 2018, 115, E7795-E7804. [CrossRef]

80. Scully, E.P. Sex differences in HIV infection. Curr. HIV AIDS Rep. 2018, 15, 136-146. [CrossRef]

81. Joseph, S.; Swanstrom, R.; Kashuba, A.D.M.; Cohen, M.S. Bottlenecks in HIV-1 transmission: Insights from the study of founder viruses. Nat. Rev. Microbiol. 2015, 13, 414-425. [CrossRef]

82. Sattentau, Q. Avoiding the void: Cell-to-cell spread of human viruses. Nat. Rev. Microbiol. 2008, 6, 815-826. [CrossRef] [PubMed]

83. Dimitrov, D.S.; Willey, R.L.; Sato, H.; Chang, L.J.; Blumenthal, R.; Martin, M.A. Quantitation of human immunodeficiency virus type 1 infection kinetics. J. Virol. 1993, 67, 2182-2190. [CrossRef] [PubMed]

84. Sato, H.; Orensteint, J.; Dimitrov, D.; Martin, M. Cell-to-cell spread of HIV-1 occurs within minutes and may not involve the participation of virus particles. Virology 1992, 186, 712-724. [CrossRef]

85. Collins, D.; Lubow, J.; Lukic, Z.; Mashiba, M.; Collins, K.L. Vpr promotes macrophage-dependent HIV-1 infection of CD4+ T lymphocytes. PLoS Pathog. 2015, 11, e1005054. [CrossRef] [PubMed]

86. Groot, F.; Welsch, S.; Sattentau, Q.J. Efficient HIV-1 transmission from macrophages to T cells across transient virological synapses. Blood 2008, 111, 4660-4663. [CrossRef] [PubMed]

87. Duncan, C.J.A.; Williams, J.; Schiffner, T.; Gärtner, K.; Ochsenbauer, C.; Kappes, J.; Russell, R.; Frater, J.; Sattentau, Q.J. High-multiplicity HIV-1 infection and neutralizing antibody evasion mediated by the macrophage-T cell virological synapse. J. Virol. 2014, 88, 2025-2034. [CrossRef]

88. Park, R.; Wang, T.; Koundakjian, D.; Hultquist, J.; Lamothe-Molina, P.; Monel, B.; Schumann, K.; Yu, H.; Krupzcak, K.; Garcia-Beltran, W.; et al. A genome-wide CRISPR screen identifies a restricted set of HIV host dependency factors. Nat. Genet. 2017, 49, 193-203. [CrossRef]

89. Jolly, C.; Kashefi, K.; Hollinshead, M.; Sattentau, Q.J. HIV-1 cell to cell transfer across an Env-induced, actin-dependent synapse. J. Exp. Med. 2004, 199, 283-293. [CrossRef]

90. Schiffner, T.; Sattentau, Q.; Duncan, C.J.A. Cell-to-cell spread of HIV-1 and evasion of neutralizing antibodies. Vaccine 2013, 31, 5789-5797. [CrossRef]

91. Lorenzo-Redondo, R.; Fryer, H.; Bedford, T.; Kim, E.-Y.; Archer, J.; Kosakovsky Pond, S.; Chung, Y.-S.; Penugonda, S.; Chipman, J.; Fletcher, C.V.; et al. Persistent HIV-1 replication maintains the tissue reservoir during therapy. Nature 2016, 530, 51-56. [CrossRef]

92. Hatano, H.; Hayes, T.; Dahl, V.; Sinclair, E.; Lee, T.-H.; Hoh, R.; Lampiris, H.; Hunt, P.; Palmer, S.; Mccune, J.; et al. A randomized, controlled trial of raltegravir intensification in antiretroviral-treated, HIV-infected patients with a suboptimal CD4 1 T cell response. J. Infect. Dis. 2011, 203, 960-968. [CrossRef]

93. Dinoso, J.; Kim, S.; Wiegand, A.; Palmer, S.; Gange, S.; Cranmer, L.; O'Shea, A.; Callender, M.; Spivak, A.; Brennan, T.; et al. Treatment intensification does not reduce residual HIV-1 viremia in patients on highly active antiretroviral therapy. Proc. Natl. Acad. Sci. USA 2009, 106, 9403-9408. [CrossRef] [PubMed] 
94. Kieffer, T.; Finucane, M.; Nettles, R.; Quinn, T.; Broman, K.; Ray, S.; Persaud, D.; Siliciano, R.F. Genotypic analysis of HIV-1 drug resistance at the limit of detection: Virus production without evolution in treated adults with undetectable HIV loads. J. Infect. Dis. 2004, 189, 1452-1465. [CrossRef]

95. Hermankova, M.; Ray, S.; Ruff, C.; Powell-Davis, M.; Ingersoll, R.; D'Aquila, R.; Quinn, T.; Siliciano, J.; Siliciano, R.; Persaud, D. HIV-1 drug resistance profiles in children and adults with viral load of $<50$ copies $/ \mathrm{ml}$ receiving combination therapy. J. Am. Med. Assoc. 2001, 286, 196-207. [CrossRef]

96. Anderson, J.; Archin, N.; Ince, W.; Parker, D.; Wiegand, A.; Coffin, J.; Kuruc, J.; Eron, J.; Swanstrom, R.; Margolis, D.M. Clonal sequences recovered from plasma from patients with residual HIV-1 viremia and on intensified antiretroviral therapy are identical to replicating viral RNAs recovered from circulating resting CD4+ T cells. J. Virol. 2011, 85, 5220-5223. [CrossRef]

97. Evering, T.; Mehandru, S.; Racz, P.; Tenner-Racz, K.; Poles, M.; Figueroa, A.; Mohri, H.; Markowitz, M. Absence of HIV-1 evolution in the gut-associated lymphoid tissue from patients on combination Antiviral therapy initiated during primary infection. PLoS Pathog. 2012, 8, e1002506. [CrossRef] [PubMed]

98. Joos, B.; Fischer, M.; Kuster, H.; Pillai, S.; Wong, J.; Böni, J.; Hirschel, B.; Weber, R.; Trkola, A.; Günthard, H. Swiss HIV cohort study TSHC HIV rebounds from latently infected cells, rather than from continuing low-level replication. Proc. Natl. Acad. Sci. USA 2008, 105, 16725-16730. [CrossRef]

99. Conway, J.; Perelson, A.S. Residual viremia in treated HIV+ individuals. PLoS Comput. Biol. 2016, 12 , e1004677. [CrossRef]

100. Kearney, M.; Wiegand, A.; Shao, W.; McManus, W.; Bale, M.; Luke, B.; Maldarelli, F.; Mellors, J.; Coffin, J.M. Ongoing HIV replication during ART reconsidered. In Open Forum Infectious Diseases; Oxford University Press: Oxford, UK, 2017; p. 4. [CrossRef]

101. Rosenbloom, D.I.S.; Hill, A.; Laskey, S.; Siliciano, R.F. Re-evaluating evolution in the HIV reservoir. Nature 2017, 551, E6-E9. [CrossRef]

102. Yukl, S.; Shergill, A.; McQuaid, K.; Gianella, S.; Lampiris, H.; Hare, C.; Pandori, M.; Sinclair, E.; Günthard, H.; Fischer, M.; et al. Effect of raltegravir-containing intensification on HIV burden and T-cell activation in multiple gut sites of HIV-positive adults on suppressive antiretroviral therapy. AIDS 2010, 24, 2451-2460. [CrossRef]

103. Buzón, M.; Massanella, M.; Llibre, J.; Esteve, A.; Dahl, V.; Puertas, M.; Gatell, J.; Domingo, P.; Paredes, R.; Sharkey, M.; et al. HIV-1 replication and immune dynamics are affected by raltegravir intensification of HAART-suppressed subjects. Nat. Med. 2010, 16, 460-465. [CrossRef] [PubMed]

104. Pierson, T.; Zhou, Y.; Kieffer, T.; Ruff, C.; Buck, C.; Siliciano, R.F. Molecular characterization of preintegration latency in human immunodeficiency virus type 1 infection. J. Virol. 2002, 76, 8518-8531. [CrossRef] [PubMed]

105. Bukrinsky, M.; Stanwick, T.; Dempsey, M.; Stevenson, M. Quiescent T lymphocytes as an inducible virus reservoir in HIV-1 infection. Science 1991, 254, 423-427. [CrossRef]

106. Hu, W.-S.; Hughes, S.H. HIV-1 reverse transcription. Cold Spring Harb. Perspect. Med. 2012, 2, a006882. [CrossRef]

107. Lesbats, P.; Engelman, A.; Cherepanov, P. Retroviral DNA Integration. Chem. Rev. 2016, 116, 12730-12757. [CrossRef]

108. Josefsson, L.; King, M.; Makitalo, B.; Brännström, J.; Shao, W.; Maldarelli, F.; Kearney, M.; Hu, W.-S.; Chen, J.; Gaines, H.; et al. Majority of CD4+ T cells from peripheral blood of HIV-1-infected individuals contain only one HIV DNA molecule. Proc. Natl. Acad. Sci. USA 2011, 108, 11199-11204. [CrossRef]

109. Josefsson, L.; Palmer, S.; Faria, N.; Lemey, P.; Casazza, J.; Ambrozak, D.; Kearney, M.; Shao, W.; Kottilil, S.; Sneller, M.; et al. single cell analysis of lymph node tissue from HIV-1 infected patients reveals that the majority of CD4+ T-cells contain one HIV-1 DNA molecule. PLoS Pathog. 2013, 9, e1003432. [CrossRef]

110. Serrao, E.; Ballandras-Colas, A.; Cherepanov, P.; Maertens, G.; Engelman, A.N. Key determinants of target DNA recognition by retroviral intasomes. Retrovirology 2015, 12, 39. [CrossRef]

111. Wu, X.; Li, Y.; Crise, B.; Burgess, S.; Munroe, D.J. Weak palindromic consensus sequences are a common feature found at the integration target sites of many retroviruses. J. Virol. 2005, 79, 5211-5214. [CrossRef]

112. Schröder, A.R.W.; Shinn, P.; Chen, H.; Berry, C.; Ecker, J.; Bushman, F. HIV-1 integration in the human genome favors active genes and local hotspots. Cell 2002, 110, 521-529. [CrossRef]

113. Lewinski, M.; Yamashita, M.; Emerman, M.; Ciuffi, A.; Marshall, H.; Crawford, G.; Collins, F.; Shinn, P.; Leipzig, J.; Hannenhalli, S.; et al. Retroviral DNA integration: Viral and cellular determinants of target-site selection. PLoS Pathog. 2006, 2, e60. [CrossRef] 
114. Ikeda, T.; Shibata, J.; Yoshimura, K.; Koito, A.; Matsushita, S. Recurrent HIV-1 integration at the BACH2 locus in resting $\mathrm{CD}^{+} \mathrm{T}$ cell populations during effective highly active antiretroviral therapy. J. Infect. Dis. 2007, 195, 716-725. [CrossRef]

115. Einkauf, K.; Lee, G.; Gao, C.; Sharaf, R.; Sun, X.; Hua, S.; Chen, S.; Jiang, C.; Lian, X.; Chowdhury, F.; et al. Intact HIV-1 proviruses accumulate at distinct chromosomal positions during prolonged antiretroviral therapy. J. Clin. Invest. 2019, 129, 988-998. [CrossRef] [PubMed]

116. Cherepanov, P.; Maertens, G.; Proost, P.; Devreese, B.; Van Beeumen, J.; Engelborghs, Y.; De Clercq, E.; Debyser, Z. HIV-1 integrase forms stable tetramers and associates with LEDGF/p75 protein in human cells. J. Biol. Chem. 2003, 278, 372-381. [CrossRef] [PubMed]

117. Lelek, M.; Casartelli, N.; Pellin, D.; Rizzi, E.; Souque, P.; Severgnini, M.; Di Serio, C.; Fricke, T.; Diaz-Griffero, F.; Zimmer, C.; et al. Chromatin organization at the nuclear pore favours HIV replication. Nat. Commun. 2015, 6, 6483. [CrossRef] [PubMed]

118. Di Nunzio, F.; Danckaert, A.; Fricke, T.; Perez, P.; Fernandez, J.; Perret, E.; Roux, P.; Shorte, S.; Charneau, P.; Diaz-Griffero, F.; et al. Human nucleoporins promote HIV-1 docking at the nuclear pore, nuclear import and integration. PLoS ONE 2012, 7, e46037. [CrossRef] [PubMed]

119. Fernandez, J.; Machado, A.K. Transportin-1 binds to the HIV-1 capsid via a nuclear localization signal and triggers uncoating. Nat. Microbiol. 2019, 4, 1840-1850. [CrossRef]

120. Burdick, R.; Delviks-Frankenberry, K.; Chen, J.; Janaka, S.; Sastri, J.; Hu, W.-S.; Pathak, V.K. Dynamics and regulation of nuclear import and nuclear movements of HIV-1 complexes. PLoS Pathog. 2017, 13, e1006570. [CrossRef]

121. Marini, B.; Kertesz-Farkas, A.; Ali, H.; Lucic, B.; Lisek, K.; Manganaro, L.; Pongor, S.; Luzzati, R.; Recchia, A.; Mavilio, F.; et al. Nuclear architecture dictates HIV-1 integration site selection. Nature 2015, 521, 227-231. [CrossRef]

122. Maldarelli, F.; Wu, X.; Su, L.; Simonetti, F.; Shao, W.; Hill, S.; Spindler, J.; Ferris, A.; Mellors, J.; Kearney, M.; et al. Specific HIV integration sites are linked to clonal expansion and persistence of infected cells. Science 2014, 345, 179-183. [CrossRef]

123. Mitchell, R.; Beitzel, B.; Schroder, A.R.W.; Shinn, P.; Chen, H.; Berry, C.; Ecker, J.; Bushman, F.D. Retroviral DNA integration: ASLV, HIV, and MLV show distinct target site preferences. PLoS Biol. 2004, 2, e234. [CrossRef] [PubMed]

124. Biggar, R.; Chaturvedi, A.; Goedert, J.; Engels, E.A. AIDS-related cancer and severity of immunosuppression in persons with AIDS. JNCI J. Natl. Cancer Inst. 2007, 99, 962-972. [CrossRef] [PubMed]

125. Hernández-Ramírez, R.; Shiels, M.; Dubrow, R.; Engels, E.A. Cancer risk in HIV-infected people in the USA from 1996 to 2012: A population-based, registry-linkage study. Lancet HIV 2017, 4, 495-504. [CrossRef]

126. Katano, H.; Sato, Y.; Hoshino, S.; Tachikawa, N.; Oka, S.; Morishita, Y.; Ishida, T.; Watanabe, T.; Rom, W.; Mori, S.; et al. Integration of HIV-1 caused STAT3-associated B cell lymphoma in an AIDS patient. Microbes Infect. 2007, 9, 1581-1589. [CrossRef]

127. Kuo, H.-H.; Ahmad, R.; Lee, G.; Gao, C.; Chen, H.-R.; Ouyang, Z.; Szucs, M.; Kim, D.; Tsibris, A.; Chun, T.-W.; et al. Anti-apoptotic protein BIRC5 maintains survival of HIV-1-infected CD4+ T Cells. Immunity 2018, 48, 1183-1194.e5. [CrossRef]

128. Archin, N.; Bateson, R.; Tripathy, M.; Crooks, A.; Yang, K.-H.; Dahl, N.; Kearney, M.; Anderson, E.; Coffin, J.; Strain, M.; et al. HIV-1 expression within resting CD4+ T cells after multiple doses of vorinostat. J. Infect. Dis. 2014, 210, 728-735. [CrossRef]

129. Zaikos, T.; Painter, M.; Kettinger, N.T.S.; Terry, V.; Collins, K.L. Class 1-Selective Histone Deacetylase (HDAC) inhibitors enhance HIV latency reversal while preserving the activity of HDAC isoforms necessary for maximal HIV gene expression. J. Virol. 2018, 92, 2110-2127. [CrossRef]

130. Shao, W.; Shan, J.; Kearney, M.; Wu, X.; Maldarelli, F.; Mellors, J.; Luke, B.; Coffin, J.; Hughes, S.H. Retrovirus Integration Database (RID): A public database for retroviral insertion sites into host genomes. Retrovirology 2016, 13, 47. [CrossRef]

131. Patro, S.; Coffin, J.M. Combined HIV-1 sequence and integration site analysis informs viral dynamics and allows reconstruction of replicating viral ancestors. Proc. Natl. Acad. Sci. USA 2019, 116, 25891-25899. [CrossRef]

132. Liu, H.; Dow, E.; Arora, R.; Kimata, J.; Bull, L.; Arduino, R.; Rice, A.P. Integration of human immunodeficiency virus type 1 in untreated infection occurs preferentially within genes. J. Virol. 2006, 80, 7765-7768. [CrossRef] 
133. Palmer, S.; Kearney, M.; Maldarelli, F.; Halvas, E.; Bixby, C.; Bazmi, H.; Rock, D.; Falloon, J.; Davey, R.; Dewar, R.; et al. Multiple, linked human immunodeficiency virus type 1 drug resistance mutations in treatment-experienced patients are missed by standard genotype analysis. J. Clin. Microbiol. 2005, 43, 406-413. [CrossRef] [PubMed]

134. Salazar-Gonzalez, J.; Salazar, M.; Keele, B.; Learn, G.; Giorgi, E.; Li, H.; Decker, J.; Wang, S.; Baalwa, J.; Kraus, M.; et al. Genetic identity, biological phenotype, and evolutionary pathways of transmitted/founder viruses in acute and early HIV-1 infection. J. Exp. Med. 2009, 206, 1273-1289. [CrossRef] [PubMed]

135. Rutsaert, S.; Bosman, K.; Trypsteen, W.; Nijhuis, M.; Vandekerckhove, L. Digital PCR as a tool to measure HIV persistence. Retrovirology 2018, 15, 16. [CrossRef] [PubMed]

136. Bruner, K.; Wang, Z.; Simonetti, F.; Bender, A.; Kwon, K.; Sengupta, S.; Fray, E.; Beg, S.; Antar, A.A.R.; Jenike, K.; et al. A quantitative approach for measuring the reservoir of latent HIV-1 proviruses. Nature 2019, 566, 120. [CrossRef]

137. Procopio, F.; Fromentin, R.; Kulpa, D.; Brehm, J.; Bebin, A.-G.; Strain, M.; Richman, D.; O’Doherty, U.; Palmer, S.; Hecht, F.; et al. A novel assay to measure the magnitude of the inducible viral reservoir in hiv-infected individuals. EBioMedicine 2015, 2, 874-883. [CrossRef]

138. Siliciano, J.; Siliciano, R.F. Enhanced culture assay for detection and quantitation of latently infected, resting CD4+ T-cells carrying replication-competent virus in HIV-1-infected individuals. Methods Mol. Biol. 2005, 304, 3-15. [CrossRef]

139. Wang, Z.; Simonetti, F.; Siliciano, R.; Laird, G.M. Measuring replication competent HIV-1, advances and challenges in defining the latent reservoir. Retrovirology 2018, 15, 21. [CrossRef]

140. Massanella, M.; Yek, C.; Lada, S.; Nakazawa, M.; Shefa, N.; Huang, K.; Richman, D.D. Improved assays to measure and characterize the inducible HIV reservoir. EBioMedicine 2018, 36, 113-121. [CrossRef]

141. Wonderlich, E.; Subramanian, K.; Cox, B.; Wiegand, A.; Lackman-Smith, C.; Bale, M.; Stone, M.; Hoh, R.; Kearney, M.; Maldarelli, F.; et al. Effector memory differentiation increases detection of replication-competent HIV-l in resting CD4+ T cells from virally suppressed individuals. PLoS Pathog. 2019, 15, e1008074. [CrossRef]

(C) 2020 by the authors. Licensee MDPI, Basel, Switzerland. This article is an open access article distributed under the terms and conditions of the Creative Commons Attribution (CC BY) license (http://creativecommons.org/licenses/by/4.0/). 